
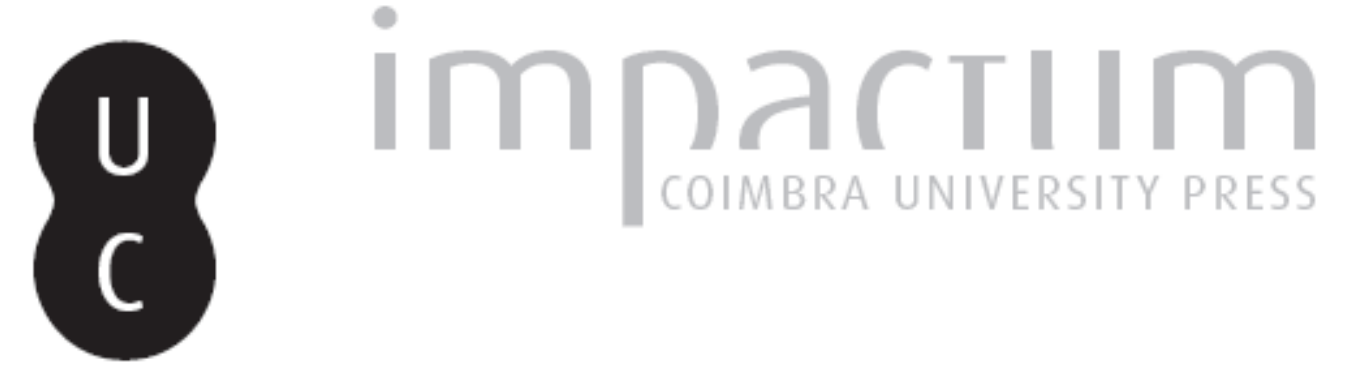

\title{
Arqueologia e ideologia: reflexões sobre um tema incómodo
}

\section{Autor(es): Mantas, Vasco Gil}
Publicado por: Faculdade de Letras da Universidade de Coimbra/Imprensa da Universidade de Coimbra

URL $\quad$ URI:http://hdl.handle.net/10316.2/41879

DOI: $\quad$ DOI:https://doi.org/10.14195/1647-8657_55_16

Accessed : $\quad$ 26-Apr-2023 09:49:55

A navegação consulta e descarregamento dos títulos inseridos nas Bibliotecas Digitais UC Digitalis, UC Pombalina e UC Impactum, pressupõem a aceitação plena e sem reservas dos Termos e Condições de Uso destas Bibliotecas Digitais, disponíveis em https://digitalis.uc.pt/pt-pt/termos.

Conforme exposto nos referidos Termos e Condições de Uso, o descarregamento de títulos de acesso restrito requer uma licença válida de autorização devendo o utilizador aceder ao(s) documento(s) a partir de um endereço de IP da instituição detentora da supramencionada licença.

Ao utilizador é apenas permitido o descarregamento para uso pessoal, pelo que o emprego do(s) título(s) descarregado(s) para outro fim, designadamente comercial, carece de autorização do respetivo autor ou editor da obra.

Na medida em que todas as obras da UC Digitalis se encontram protegidas pelo Código do Direito de Autor e Direitos Conexos e demais legislação aplicável, toda a cópia, parcial ou total, deste documento, nos casos em que é legalmente admitida, deverá conter ou fazer-se acompanhar por este aviso.

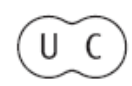


CONIMBRIGA

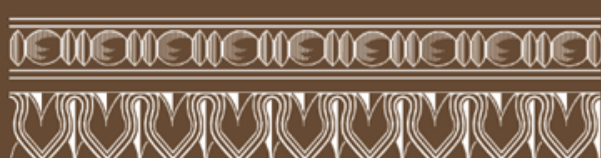

INSTITUTO DE ARQUEOLOGIA

VOLUME LV • 2016

FACULDADE DE LETRAS
UNIVERSIDADE DE COIMBRA 
Vasco Gil Mantas

Faculdade de Letras da Universidade de Coimbra

vsmantas@gmail.com

ARQUEOLOGIA E IDEOLOGIA.

REFLEXÕES SOBRE UM TEMA INCÓMODO

ARCHAEOLOGY AND IDEOLOGY.

REFLECTIONS ON AN UNCONFORTABLE TOPIC

"Conimbriga" LV (2016) p. 305-348

https://doi.org/10.14195/1647-8657_55_16

Resumo: A permeabilidade das ciências humanas às pressões e condicionalismos característicos de determinadas épocas ou regiões tem motivado acesas discussões, nem sempre conduzidas com a imparcialidade e o rigor exigíveis. Trata-se de um fenómeno identificável em todos os regimes, por razões políticas ou outras, com notável desenvolvimento sempre que se verifica a necessidade de reforçar ou criar identidades nacionais ou étnicas. Um dos efeito da utilização ideológica da arqueologia, envolve a destruição sistemática de património arqueológico, sobretudo quando considerado simbólico, situação que repete outras anteriores, com um agravamento de consequências ainda imprevisíveis.

PalaVras-chave: Arqueologia, Ideologia, Conflitos.

ABSTRACT: The perviousness of the social sciences op the pressures and constraints of a given time or region motivates heated debates, which are not always conducted with the proper impartiality and thoroughness. This is a phenomena that can be identified in all regimes, for political or other reasons, com notable development whenever it is necessary to reinforce or create national or ethnical identities.

Conimbriga, 55 (2016) 305-348 
One of the consequences of using archeology in ideology includes the systematic destruction of archaeological sites, most notably when held as symbolic, something that happens repeatedly, with still unpredictable consequences.

KeYwOrds: Archaeology, Ideology, Conflicts. 


\section{ARQUEOLOGIA E IDEOLOGIA. REFLEXÕES SOBRE UM TEMA INCÓMODO}

Uma das personagens de Noite e Dia, conhecido romance de Virgínia Woolf, distraindo-se no Museu Britânico na observação dos mármores Elgin deixa-se elevar a sentimentos de prazer estético, de beleza pura, que acabam, qual corrente da consciência, por conduzi-la a reflectir sobre o amor e a pessoa amada (Woolf 2012 73-74). Pode parecer deslocada esta introdução, não tanto pela alusão aos discutidíssimos monumentos levados para Londres por Lorde Elgin (BOARDMAN 1964 9-14,130-133), mas por invocar uma relação aparentemente absurda entre emoções amorosas e arte antiga, ou, se quisermos ser mais abrangentes, arqueologia. Na verdade, não é assim, pois definindo a arqueologia como the exercice of controled imagination, de acordo com a afirmação de Bradford (BRADFORD 1957 viii), estamos perante uma realidade que, pela sua natureza, não se pode circunscrever rigidamente ao campo científico com exclusão de outros, tal como sucede com as ciências humanas em geral, em grande parte ciências da Memória.

Sem desejarmos retirar à arqueologia a condição de ciência por direito próprio (MANTAS 2007 33), não podemos ignorar esta questão essencial. Por isso, da mesma forma que a observação dos mármores Elgin permitiu a Mary Datchet destacar-se da realidade objectiva para mergulhar em devaneios românticos, que nunca são totalmente alheios à realidade, também a arqueologia se presta a diversões mais ou menos à margem do que se pensa científico. Será esta circunstância exclusiva das ciências humanas, por vezes assumida como um pecado original, motivador de uma situação de menoridade inultrapassável? Ora, na verdade, não faltam exemplos na área das ciências exactas de evidentes derrapagens, cujas causas são, com frequência, as mesmas que prejudicam a história e a arqueologia quando confrontadas com pressões sociais incontornáveis. E não sejamos ingénuos, pois uma e outra, sofrem de igual prejuízo, apesar da prática arqueológica aparentar maior apro- 
ximação a exigências técnicas consideradas científicas. Mas o problema não se prende, nem assim poderia ser, com uma simples divergência de metodologias, pois a questão central reside na interpretação das fontes, sejam elas arqueológicas ou escritas, e neste caso a arqueologia ainda se revela mais vulnerável.

Passemos, pois, ao que mais directamente nos interessa, recordando um passo de Ernst Jünger que nos parece esclarecer o que dissemos, tanto mais que não se trata de um arqueólogo e o que escreveu tem valor universal, embora certamente pensado para um contexto muito marcado, o da Alemanha nacional-socialista: Como todo o teórico grosseiro, alimentava-se também daquilo que a ciência oferecia de menos intemporal, praticando em especial a arqueologia. Não era suficientemente perspicaz para suspeitar de que a nossa pá põe infalivelmente a descoberto aquelas coisas que nos vivem na mente, pelo que, como já muitos outros antes dele, julgava ter descoberto a sede primitiva do género humano (JÜNGER 1995 145-146).

Ora, este passo do escritor alemão sublinha claramente o problema, central na prática arqueológica, da interpretação. Naturalmente, se nos limitarmos a descrever um objecto, evitando a tentação da sua explicação em termos sociais, acto simplificado que para alguns corresponde à função primordial da arqueologia, excluímos as dificuldades interpretativas, mas renunciamos ao discurso histórico, adoptando uma inaceitável atitude redutora. Devemos dizer desde já que, em determinadas sociedades não foi e não é possível concretizar a actividade arqueológica sem que ela funcione como suporte dito ou considerado científico de interpretações ao serviço de atitudes ideológicas. A arqueologia é particularmente vulnerável a este tipo de manipulação por corresponder a uma actividade científica cujos resultados permitem, manuseados, sustentar ideias falsas ou deturpadas, assegurando-lhes credibilidade. Nestas situações, os resultados do acto interpretativo, através de um processo mais ou menos elaborado de representação, termina por conduzir à sua finalidade como generalização simbólica, maioritariamente pertencente ao campo do imaginário ou do mítico.

Mesmo em condições normais, ou seja, quando a pressão sobre os arqueólogos resulta apenas das condições materiais da investigação ou dos lugares comuns vigentes numa determinada sociedade, a explicação do objecto em causa resulta frequentemente difícil sempre que pretenda, como deve, ultrapassar a simples descrição (ALARCão 1997 11-32; Alarcão 2000). Consideremos outro exemplo literário, neste 
caso através de Somerset Maugham, o do achado algures na China, na periferia do Tibete, de um troço de estátua grega, eventualmente representando Alexandre. A classificação do fragmento como de origem grega não levantou dúvidas, mas a forma como foi sentida pelo seu autor abre-nos caminho para questões mais sérias: Falava-me uma linguagem que me era familiar. Repousava-me o coração. Até aqui, identificação, sentimento de pertença, ou seja, aquilo que nos diferencia dos outros, enquanto comunidade cultural. E este sentimento vai predominar sobre a explicação histórica, passando rapidamente ao campo das leituras simbólicas, facilmente transmissível a públicos numerosos, mesmo educados, ou talvez por isso: Que magnificência não evocava aquele devastado fragmento de mármore, e que aventuras! Quanto tempo terá durado o reino e que tragédia assinalaria a sua queda? Ah! Eu não podia olhar as bandeiras tibetanas, nem as taças verdes; pois eu via o Parthenon, na sua beleza, e, mais além, o azul tranquilo do mar Egeu (MAUGHam s/d 211-214).

A utilização do monumento mais prestigioso da Grécia antiga como símbolo, não poucas vezes ambíguo, de identificações, continuidades ou heranças, é redundante e por vezes perturbadora pelo contexto em que ocorre, embora perfeitamente compreensível. Recordamos que num folheto relacionado com uma reunião científica na ilha dinamarquesa de Bornholm, foi aquele templo ateniense escolhido para tutelar a informação disponibilizada, embora não faltem em Bornholm testemunhos pré-históricos e medievais significativos. É evidente que, no início do século XXI, recorrer ao Parthenon como logótipo de uma reunião na Dinamarca reflecte claramente a identificação ideológica com valores fundacionais, em que à Grécia, pátria da democracia, era atribuído um lugar essencial (Rocha PEREIRA 2008 11-24), pelo menos antes de se tornar alvo de críticas generalizadas surgidas na sequência de uma crise económica de que os gregos não são certamente os únicos culpados, tornados agora símbolos de sinal contrário.

Como é evidente, a leitura dos símbolos só tem sentido no seu contexto próprio, o que, mesmo assim, nem sempre é fácil. Lembramos, a este propósito, o discutido e recorrente tema da chamada decoração astral, com frequência considerada característica do mundo céltico, esquecendo ou ignorando a sua forte ocorrência em lugares como Israel ou Marrocos, assim como os complexos processos difusionistas que conheceu, nomeadamente no mundo romano (MARCo / Abásolo ÁLVAREZ 1995 327-359). Na interpretação dos símbolos, e o mesmo sucede com 
a interpretação tendenciosa de determinados fenómenos históricos, o princípio repetitivo desempenha uma função primordial, sobretudo se uma opinião contrário for marginalizada ou considerada, por alguma razão, imprópria. Basta recordar as polémicas que têm envolvido ultimamente a Turquia a propósito do problema arménio e grego e das estranhas afirmações sobre a descoberta da América convictamente proferidas pelo presidente deste país.

Socorremo-nos de outro exemplo literário para ilustrar esta questão, neste caso a leitura da perturbante obra de Pierre Boule, O Planeta dos Macacos, cujas adaptações cinematográficas a não dispensam, na qual encontramos o exemplar episódio do jovem investigador que descobre provas arqueológicas inquestionáveis de que os humanos foram, no passado, falantes e civilizados, opinião imediatamente condenada e sancionada pela academia dominada pelos defensores das verdades oficiais (Boule s/d 165-175). Ficção científica ou reflexo de realidades sempre presentes quando a ideologia se intromete com a investigação, como tão frequentemente sucede e, por vezes, quando e onde menos se espera? Não duvidamos em optar pela última hipótese, pois o problema é o do estabelecimento de uma verdade oficial ou oficializada.

A distorção dos dados arqueológicos, tal como a de outras fontes históricas, pode ser involuntária, não abrangendo neste caso os especialistas da matéria, o que já não sucede quando é voluntária, quase sempre motivada por razões políticas, religiosas ou económicas, não raramente associadas. Neste contexto podem ser atribuídos valores opostos ao mesmo monumento, positivos ou negativos consoante a interpretação partilhada por quem o avalia. Se é verdade que muitos monumentos arqueológicos foram, e são, vítimas de destruição por razões políticas ou religiosas, o mesmo acontece por razões económicas. Poderíamos recordar apenas as irreversíveis perdas causadas pela construção de grandes barragens ${ }^{1}$, mas não podemos esquecer os estragos no património arqueológico provocados injustificadamente em nome de interesses económicos, dos quais todos conhecemos um ou outro caso, a coberto de um progresso de objectivos pouco claros, dificilmente contestável em termos sociais.

\footnotetext{
${ }^{1}$ Como sucedeu em Portugal com a construção da barragem de Alqueva, apesar das acções de emergência efectuadas no sentido de limitar os estragos. A perda do Castelo da Lousa, só por si, é lamentável. E estará a barragem, cuja construção se politizou a partir de determinado momento, a cumprir os seus objectivos económicos?
}

Conimbriga, 55 (2016) 305-348 
Não faltariam exemplos destas situações, algumas dificilmente admissíveis, se aqui as desejássemos indicar, o que nos afastaria do tema central desta reflexão, ainda que a economia se revista de aspectos ideológicos muito pertinentes, em que a eficiência e a rentabilidade são normalmente os factores mais valorizados. Basta recordar a voga da eufemisticamente chamada requalificação de monumentos antigos, descaracterizando-os ou transformando-os em simples pastichos, de que o acontecido no teatro romano de Sagunto, em Espanha é um excelente exemplo (MANTAS 2008 179-180), tudo em nome de uma pretensa recuperação das ruínas para novas funções, quando não apenas para satisfazer o gosto do turismo de massa por cenários vagamente antigos, não hesitando em sacrificar com bárbara indiferença o que é verdadeiro, embora arruinado, demolindo-o, ocultando-o ou descaracterizando-o.

Não rareiam, também entre nós, exemplos desta moda perversa, com a infelicidade de frequentemente deixar de parte os arqueólogos, transferindo o nível de decisão para os que se deveriam limitar a aspectos técnicos e estéticos. Perante o que se vai vendo parecem-nos exageradas as constantes críticas aos trabalhos desenvolvidos pela desaparecida DGEMN, a integrar no Zeitgeist da época, preocupado com uma maneira de fazer portuguesa. Deixemos por ora esta questão, a merecer uma análise cuidada, pois envolve com frequência aspectos ambíguos, onde a economia e a política se conjugam, por vezes harmoniosamente. É o caso da Muralha da China, ou melhor, de uma das muralhas, a da Dinastia Ming, estrutura defensiva complexa (SCHWARTZ / ZHewen 2001), deixada longamente ao abandono e muito destruída por não se lhe reconhecer interesse simbólico nem valor material, situação que se alterou nos últimos anos por evidentes razões económicas relacionadas com os fluxos turísticos e, simultaneamente, pelo facto da Grande $\mathrm{Mu}$ ralha simbolizar agora o esforço colectivo dos Chineses e não o resultado do despotismo desta ou daquela dinastia.

Não esqueçamos que, na actualidade, grande parte da ideologia se baseia em simples pressupostos economicistas, segundo os quais o correcto e o incorrecto se identificam com o factor rentabilidade, pelo que não nos devemos admirar quando até museus de renome colocam peças à venda em leilões, abrindo novo campo à já de si complicada polémica do direito à devolução de obras obtidas de forma vagamente legal nos países que agora as reclamam, alguns dos quais de formação recente. É claro que, no século XIX e durante grande parte do século XX, muitas destas aquisições nem eram resultantes de guerras ou de saques 
mais ou menos organizados, como agora vai sucedendo diariamente, mas assentavam numa prática comum nas escavações oficiais, como nos explicou Agatha Christie numa obra que todos os arqueólogos deviam ler: $O$ momento escaldante da "divisão" aproxima-se. No final da temporada o director dos Services des Antiquités vem ou manda um representante, para dividir todos os achados dessa temporada. No Iraque isso costumava ser feito objecto a objecto, e geralmente levava vários dias. Na Síria, porém, o sistema é muito mais simples. Cabe a Max dividir em duas partes tudo aquilo que foi encontrado, da maneira que lhe apetecer. Depois o representante sirio vem, examina as duas séries de objectos e escolhe aquela que quiser que fique para a Síria. Em seguida a outra é embalada e despachada para o Museu Britânico (Christie 2010 235-236).

Cremos ser altura de nos ocuparmos de alguns casos de interferência, directa ou velada, de opções ideológicas nas actividades arqueológicas ou na divulgação dos seus resultados reais ou imaginários, sem esquecer aquelas situações em que o património arqueológico, assumido simbolicamente, é exaltado por uns e destruído por outros. Desta forma não nos é difícil compreender que Saddam Hussein tivesse o seu nome inscrito em tijolos da "reconstruída" Babilónia (FIG. 1), circunstância que tem o seu oposto ideológico, se a tanto o promovermos, no vendaval de destruição protagonizado pelo movimento jihadista no Iraque e na Síria. Da indiferença pelo monumento passou-se, facilmente, ao ódio pelo mesmo enquanto símbolo. Poderíamos recuar alguns séculos mas entendemos concentrar as nossas observações na época contemporânea com particular enfâse no século XX e nestes anos conturbados e premonitórios do século XXI, que tão nocivos se vêm revelando para patrimónios dos quais nos continuamos a proclamar cada vez mais timoratos herdeiros.

A referida interferência não é, todavia, uma invenção do mundo contemporâneo, embora o fortalecimento dos estados nacionais tenha contribuído para o processo, tanto mais que muitos deles são falsos estados, fundamentando em bases políticas a parceria ideológico-científica de que falamos, nem sempre, é certo, com os mesmos objectivos, mas assente numa teia centrada no recurso à investigação para confirmar ou infirmar uma realidade ou o que assim se considera à luz de uma qualquer autoridade. Os eruditos que, já em pleno Iluminismo, nos deixaram copiosas páginas sobre a fundação desta ou daquela povoação por figuras bíblicas ou da tradição clássica não o faziam irreflectida- 
mente e acreditavam no que escreviam, agindo de acordo com o ambiente sócio-cultural da sua época e quadro civilizacional.

Não deixa de ser interessante verificar que a busca de confirmação através da prática de escavações, preludiando uma atitude científica, ocorre cedo em Portugal, ainda que no campo da hagiografia e de forma tendenciosa, como foi o caso da escavação de uma necrópole romana perto do santuário dos Santos Mártires, nos arredores de Tomar, em 1659, relacionando-a, como se pretendia, com os mártires de Concordia, oportunamente situada na Beselga (MANTAS 2012 309), fazendo, desta forma, a conclusão anteceder a prova: testemunhos arqueológicos correctos comprovando, através de uma metodologia ao inverso, uma tese claramente fantasista. Seja como for estamos perante um caso claro de arqueologia condicionada ideologicamente, engagé, diriam os nossos amigos francófonos.

Nem sempre é fácil, num contexto de uso consciente da arqueologia como suporte ideológico, separar as intenções políticas de outras ditadas por aspectos culturais, no sentido mais alargado do termo. Aliás, são estes aspectos que facilitam ou determinam as situações que vamos referir em seguida, infelizmente vividas na actualidade com uma violência incomum, embora não inédita, e que obriga a repensar de forma pragmática os lugares comuns do discurso político contemporâneo, incapaz de sustentar o confronto com as realidades que tornam o fim da história um mito infantil e perigoso. O tema aqui esboçado levar-nos-ia longe, exigindo páginas de que não dispomos. Passamos, pois, a desenvolver rapidamente algumas referências a situações envolvendo cumplicidade e conflitualidade entre arqueologia e política, entendidas senso lato e na base do binómio identificação / rejeição.

Um dos aspectos a considerar é o da influência maior ou menor da valorização deste ou daquele período histórico sobre a arqueologia, em particular a nível nacional envolvendo questões de identidade (RowlANDS 1994 129-143), atitude da qual resultou, ou resulta ainda, a atribuição privilegiada de meios para desenvolver programas de investigação. Esta situação, que acompanhou o apogeu do ensino público das Humanidades nos séculos XIX e XX, conhece hoje alterações significativas ditadas não menos do que antes por razões de estratégia política, como acontece na União Europeia quando se busca uma plataforma histórico-cultural suficientemente ampla para nela inserir países ou regiões com características específicas, elegendo a Idade do Bronze, o Celtismo ou a Antiguidade Tardia como referências unificadoras (GRA-

Conimbriga, 55 (2016) 305-348 
ves-Brown / Jones / GAMBLE 1996; Jones 1997 1-14), mais amplas ou mais vagas que o modelo imperial romano (WARD-PERKINS 2003 9-22, 225-244), ainda que este seja largamente apontado como exemplo teórico a observar pela União Europeia (MANTAS 2012a 47-73), confrontada com problemas de aculturação e de imigração que se vão tornando dramaticamente impossíveis de gerir e cujos reflexos se encontram em inesperados contextos visionários, nem por isso menos merecedores de profunda reflexão (HouELLEBECQ 2015 138-141, 254-255)

A valorização da pesquisa arqueológica vocacionada para determinado período pode relacionar-se facilmente com as correntes nacionalistas e que se foram desenvolvendo e em certos casos, renovando, desde que a arqueologia ganhou estatuto de autêntica ciência. O papel central da Europa neste processo deve ser considerado sem complexos, tanto mais que a lógica que o condicionou se estendeu a outras regiões do globo culturalmente afins e por isso mesmo interessadas nas mesmas temáticas. Estão neste caso a chamada Arqueologia Bíblica e a Arqueologia Clássica, praticadas dos dois lados do Atlântico desde muito cedo, por razões religiosas e de educação humanística. Como é natural, o desenvolvimento dos impérios coloniais estimulou a investigação de outras realidades culturais, surgindo estudos de grande mérito sobre arqueologia islâmica ou indiana, por exemplo, ainda que muitas vezes marcados por um forte eurocentrismo reflectindo a pertença a um lugar considerado privilegiado, característico das políticas identitárias (Rose 1995 87-105). Recordamos, a propósito, a afirmação atribuída a Platão: O que nós, Gregos, tomamos dos estrangeiros, transformamo-lo em algo mais belo (PseUdo-Platão Epin. 987).

Casos particularmente interessantes são os da Egiptologia e da Assiriologia (SAUNERON 1968 5-29; GARELLI 1972 5-41), especialidades cujo início antecede o domínio europeu sobre o Crescente Fértil e que, abstraindo dos aspectos bíblicos, dificilmente se podem inserir na ideia de identidade cultivada na Europa do século XIX. Todavia, se considerarmos o enorme esforço de projecção científica internacional empreendido na época pelos principais estados europeus, no cenário de afirmação nacionalista próprio do período, facilmente se compreende o sucedido. De outra forma não existiriam as grandes colecções dos museus de Londres, Paris ou Berlim, hoje tão discutidas à margem do fundamental papel de salvaguarda de patrimónios inestimáveis que têm desempenhado. Não vale a pena ser maniqueísta, pois sem a intervenção ocidental é evidente que não só testemunhos essenciais das antigas 
civilizações asiáticas e africanas se teriam perdido, como a sua historiografia conheceria um ritmo de desenvolvimento muito mais lento. Lembramos o que Sabatino Moscati escreveu sobre os resultados da investigação levada a efeito no Próximo Oriente no período entre as duas guerras mundiais para que se reconheça o alcance científico de tais investigações (MosCATI 1963 3-8), em certos casos iniciadas ainda antes de 1914 no âmbito da diplomacia ou da espionagem, em particular nos territórios otomanos (RICHTER 2008 212-240).

Também em Portugal, apesar da modéstia da arqueologia nacional e da circunstância dos territórios ultramarinos não se prestarem a revivalismos como os que marcaram a ideologia imperial britânica, francesa e italiana, encontramos, nos séculos XIX e XX, uma preocupação identitária acolhida pelas elites e através delas popularizada, sobretudo pela via do ensino primário e secundário. Herdeiros de uma prestigiosa história marítima, da qual o período medieval de afirmação da Nacionalidade era considerado o prólogo, os ideólogos portugueses desenvolveram, naturalmente, uma leitura da história centrada nos valores cristãos e civilizadores, não se deixando tentar por identificações com a Antiguidade Clássica, como evidencia tanto a literatura como a ubíqua arquitectura neomanuelina (ANACLETo 1994). Todavia, desde o século XIX que se debate a questão da origem do povo português, o que tem alguma coisa a ver com o desenvolvimento precoce da arqueologia pré-histórica nacional, quando comparada com a de outros períodos.

Num Estado-Nação como Portugal não era difícil defender a tese da continuidade entre os Portugueses actuais e os Lusitanos, como o fez Leite de Vasconcelos, claramente contrário à visão medievalista de Oliveira Martins (Matos 1994 11-33), tese que ganhou ainda maior desenvolvimento com Mendes Corrêa ao afirmar para a população portuguesa uma origem autóctone ainda mais antiga (CORRÊA 1924). Desta forma, todos os povos que contribuíram para a formação cultural e étnica dos Portugueses ao longo de milénios eram considerados como invasores, elementos exóticos em oposição mais ou menos aberta aos indígenas. É claro que esta interpretação da história antiga do território português, valorizando a ascendência lusitana (ENCARNAÇÃo 1993-1994 35-42), não foi caso único nem pode ser considerada típica dos regimes autoritários que se desenvolveram na Europa no século XX, tanto mais que os encontramos em data anterior e em países como a França, onde a escola pública ensinava serem os Gauleses os antepassados dos jovens franceses (BRUNO 1877 133). Como é evidente, esta interpretação unitária das 
origens conheceu em Portugal dificuldades a partir de meados do século passado, tornando-se politicamente inadequada, tal como o seu símbolo máximo, Viriato (GUERRA / FABIÃo 1992 9-23).

Um excelente exemplo do que dizemos, ainda que a maioria dos visitantes não se apercebam do discurso histórico produzido, é o conteúdo formal do Portugal dos Pequenitos (OliverRa 2004 40-56), belo parque temático conimbricense delineado por um reconhecido opositor ao regime, Cassiano Branco, cuja construção se iniciou, por iniciativa de Bissaya Barreto, em 1938. Ora, as referências ao período anterior à Nacionalidade reproduzem linearmente a doutrina oficial quanto às origens portuguesas, notando-se a influência das teses de Mendes Corrêa na curiosa anta que coroa no Portugal dos Pequenitos a mina do Cabo Mondego. Não se encontra nenhuma alusão à presença romana, à qual o programa de história do Ensino Primário apenas reconhecia a origem da língua, a construção de monumentos, o municipalismo e, sobretudo, a introdução do Cristianismo (BARRos s/d 4-8). Quanto ao período islâmico, agora em voga ${ }^{2}$, o único apontamento visível no Portugal dos Pequenitos consiste nos combatentes mouros tombados sob o cavalo do Rei-Fundador, o que dispensa qualquer comentário, tão imediata é a interpretação do monumento. Na mesma linha nacionalista se situaram as escavações conduzidas pelo coronel Afonso do Paço no campo de batalha de Aljubarrota, em 1956 e 1957, aliás com resultados um tanto contrários à versão oficial do prélio (PAÇo 1965). Em conclusão, podemos considerar que os esforços dos humanistas portugueses para valorizar a herança latina, e basta lembrar André de Resende e Francisco de Holanda (RESENDE 2009; Holanda 1984), não tiveram eco político assinalável em tempos posteriores, precisamente por não se apresentarem ideologicamente operacionais (FABĨ̃o 1996 90-107).

$\mathrm{Na}$ vizinha Espanha, onde os regionalismos e as especificidades culturais se fazem sentir com muito maior acuidade, a arqueologia foi envolvida no debate entre o Celtismo e o Iberismo em oposição a outros contributos étnico-culturais, valorizando-se ciclicamente as opiniões que valorizavam uma interpretação unitária (RUIZ ZAPATERO 1996 179-195). Mais abertos à influência romana, embora não descurando a presença germânica, patente na base da teoria da Reconquista,

${ }^{2} \mathrm{O}$ que talvez explique a proliferação de publicações com títulos árabes, entre outros exotismos.

Conimbriga, 55 (2016) 305-348 
os arqueólogos do país vizinho dedicaram-se largamente à prática da arqueologia clássica, ao que também não foi alheio um forte contributo de investigadores estrangeiros, em particular alemães e franceses. Como é compreensível, durante o regime franquista, nacionalista e unitário, a Antiguidade foi interpretada de forma a favorecer aspectos unificadores do passado espanhol (PoLo 2014 571-578), sem esquecer a resistência oposta à conquista romana, de que as ruínas de Numância representavam um símbolo ideal, por se tratar de um grande povoado celtibérico cuja queda após uma resistência desesperada representou, poucos anos depois da morte de Viriato, o golpe decisivo na resistência peninsular aos Romanos.

Devemos sublinhar que a valorização do episódio não foi exclusiva do imaginário franquista, remontando à tragédia de Cervantes $L a$ Numantia, redigida cerca de 1582 (VIVAR 2000 7-30); no século XIX, uma fragata foi baptizada como Numancia ${ }^{3}$, o mesmo sucedendo com uma unidade da actual Armada espanhola (F 83). Como é evidente, as questões nacionalistas ultrapassam facilmente os regimes. Seja como for, e apesar do período romano ser particularmente valorizado pela introdução do Cristianismo, chegou a desenvolver-se, sobretudo por influência de António Almagro, a tese da hispanização de Roma (PoLO 2009 3-10), uma espécie de romanização à l'envers na qual o aspecto religioso constituía elemento relevante, tese que não deve ser confundida com idêntica designação atribuída mais recentemente ao ascendente atingido durante os Antoninos pelas elites hispânicas no governo e políticas do Império. Sem que houvesse uma identificação com a romanidade, à qual se reconhecia o legado da Lei e da Unidade, não deixou de se cultivar uma certa estética romanesca, classicista, talvez induzida por via italiana, patente, por exemplo, no Arco da Vitória (FIG. 2), em Madrid (ATARD 1971), cujos esboços iniciais remontam a 1942, embora a construção se tenha iniciado mais tarde ${ }^{4}$, arrastando-se até 1956. As escavações lentamente desenvolvidas em sítios de prestígio internacional (DiaZ-ANDReu / RAmíreZ-SÁnchez 2007 109-130), como Mérida,

${ }^{3}$ A Numancia, construída em França, foi o primeiro navio couraçado a circum-navegar o globo, entre 1865 e 1867 . Teve uma vida muita activa, naufragando em Sesimbra, em 1916, quando seguia a reboque para demolição em Bilbau.

${ }^{4}$ Presentemente esboça-se um movimento de opinião, inspirado na Lei da Memória, exigindo a demolição do monumento, o que consideramos um erro político e cultural. Com ou sem pedras, a história existe e o ambiente actual não aconselha tais atitudes. 
e o relativo respeito demonstrado por alguns monumentos romanos durante a construção da barragem de Alcântara, por exemplo, demonstram a abertura do regime à herança romana como um valor da civilização ocidental. O estabelecimento do protectorado em Marrocos, onde se efectuaram escavações importantes em Lixus e em Tamuda aproveitou em parte a ideia da reconstituição da Mauritania Gaditana do Baixo-Império romano (VILLAVERDE VeGA 2001 60-63, 71-73).

O uso da Antiguidade europeia no discurso ideológico imperial foi muito mais forte nos países que dominaram territórios onde os vestígios do mundo romano eram mais evidentes e imponentes. Todavia, nem sempre podemos relacionar esta atitude com o passado desses países ou com a sua real ou pretendida continuidade racial, em parte defensável para a Itália e para a França, implausível quanto ao Reino Unido, onde o fenómeno teve particular importância, apesar de só muito tardiamente terem assumido o controlo de espaços outrora pertença do mundo romano. No caso britânico deparamos com a adopção intelectual de uma atitude equiparando os dois impérios e as suas missões civilizadoras, destinando-se o Império Britânico a ultrapassar em grandeza o seu modelo ideológico, o Império Romano, como a inscrição no belo e fantasista monumento comemorando a rainha rebelde Boudica (SEALEY 1997), em Londres, proclama: Regions Caesar never knew / Thy posterity shall sway (COWPER 1818 32).

A importância da educação humanista das elites britânicas, de alguma forma considerada preparatória do exercício do poder e formadora de valores morais e políticos nos quais se enquadrava perfeitamente o serviço imperial (JONES 2008 26-49), teve um papel decisivo na forma como o legado romano foi incorporado na cultura do Reino Unido, inclusive através de narrativas destinadas aos mais jovens, como as de Rudyard Kipling (KIPLING 1906). Desta forma, não é de estranhar o interesse que os arqueólogos britânicos demonstraram pelas antiguidades romanas, sem esquecer, naturalmente, os períodos anteriores e posteriores ao domínio romano, menos convenientes, pelo menos de forma directa, ao discurso imperial. Devemos sublinhar, contudo, o enorme trabalho desenvolvido fora da Europa, em regiões de velhas civilizações como o Próximo Oriente, a Índia e o Paquistão, bem representado por arqueólogos como Mortimer Wheeler (PIgGotT 1977 623-642; GuHA 2003 4-10), polifacetada figura da arqueologia do século XX.

$\mathrm{O}$ estudo do grupo social em que se situavam maioritariamente os arqueólogos britânicos durante grande parte do século passado, permi- 
te compreender facilmente as suas relações com a ideologia imperial (TAYLOR 1995 499-509), antes de agora encontramos parte deles comprometidos com um discurso regionalista, por vezes radical, e com a crítica das visões coloniais do passado, por vezes não menos ideológica do que a daqueles que censuram (MatTingly 1997; MofFat 2005 226). A arqueologia, por outro lado, e não apenas no caso britânico, teve com frequência aspectos ambíguos, prestando-se a cobrir actividades menos científicas, sobretudo nos finais do século XIX e primeiras décadas do XX (SATIA 2008 3-19), particularmente quando tais actividades se desenvolviam no estrangeiro. Recordamos a extraordinária acção da inglesa Gertrude Bell (FIG. 3), que viria a criar o Museu de Bagdade (Winstone 2004), figura muito próxima do famoso T. E. Lawrence ${ }^{5}$, assistente de Leonard Woolley na escavação do sítio hitita de Karkemish, no Eufrates, empreendida entre 1911 e 1914 pelo Museu Britânico, e simultaneamente agente secreto ocupado no estudo do caminho-de-ferro otomano Istambul-Bagdade, construído pelos alemães. Lawrence era um excelente conhecedor da região, incluindo o deserto de Negueve, o que se revelou decisivo na condução da Revolta Árabe contra o domínio turco (MACK 1998 68-165).

Outro aspecto a ter em conta na sociedade britânica, sobretudo no período anterior à Grande Guerra, é o da interacção da arqueologia com certas correntes, artísticas ou religiosas, quando não mesmo esotéricas, como no caso da ligação de monumentos megalíticos, com particular destaque para Stonehenge, ao druidismo e às suas versões revivalistas. Uma popular figura da sociedade vitoriana, o general Charles Gordon, morto na defesa de Cartum em 1885, homem de fortes convicções, dedicou-se também a estudos de arqueologia bíblica, tentando identificar a localização do Paraíso e da colina do Calvário, em Jerusalém (WILKINSON 1978 146-147, 198-200). Embora muitas destas figuras não possam situar-se no círculo dos arqueólogos profissionais, se podemos utilizar o conceito para a época, não deixa de se verificar o significativo impacte, sobre as classes cultas, dos estudos arqueológicos então desenvolvidos, passando através destas a camadas sociais mais amplas.

Uma imagem mais ou menos romântica da Antiguidade, cuja uti-

\footnotetext{
${ }^{5}$ Sobre a actividade de Gertrude Bell, largamente inspiradora da criação do Estado iraquiano, foi lançada recentemente (2015) uma película pouco conseguida, protagonizada por Nicole Kidman.
}

Conimbriga, 55 (2016) 305-348 
lização ideológica foi por vezes evidente, encontra-se difundida através da produção de diversos artistas, merecendo sublinhar neste caso a obra do pintor Lawrence Alma-Tadema, que abrange assuntos que vão da História Bíblica à Antiguidade Tardia, ainda que se distingam os trabalhos relativos ao mundo romano, tratados com grande pormenor (FIG. 4), não isentos pontualmente de algum espírito crítico (SwANSON 1977; MANTAS 2008a: 71-78), afastando esta interpretação do sonho romano vitoriano quer dos lugares comuns eróticos ${ }^{6}$, quer das inumeráveis ruínas nascidas do pincel dos pompiers (BRETON 2010), inspirados nas escavações de Pompeios. As representações da Antiguidade, por se tratar de representações, ou seja, de tentativas de identificação, não podem, como a própria Arqueologia, escapar às ideias preponderantes em determinada época e na classe social dominante, expressa na ideologia política, seja qual for a sua orientação.

A mesma cultura neoclássica estendeu-se às margens ocidentais do Atlântico, onde os Estados Unidos da América iniciavam a marcha para a sucessão ao poder global britânico, que levaria, inevitavelmente, a comparações com o Império Romano (MurPhy 2007; Pearson 2008). Esta relação com a Antiguidade revelou-se tanto na simbologia nacional como na grande arquitetura neoclássica, talvez mais fácil de desenvolver na América, por razões históricas e pragmáticas, quando se tratou de encontrar modelos inspirados pela arquitectura romana para grandes edifícios emblemáticos do progresso técnico, ideia concorde com o espírito norte-americano, como sucedeu com a famosa Pennsylvania Station, em Nova Iorque (FIG. 5), inspirada nas Termas de Caracala, em Roma. Construída nos primeiros anos do século XX foi demolida em 1963, apesar da contestação que o facto suscitou, verberado num editorial do New York Times da seguinte forma: No one was convinced that Penn Station really would be demolished or that New York would permit this monumental act of vandalismo against one of the largest and finest landmarks of its age of Roman elegance (HuXTABLE 1963).

Talvez menos subjectiva que a britânica foi a atitude francesa envolvendo as relações entre arqueologia e ideologia ao longo dos séculos XIX e XX. Dois factores evidentes explicam, pelo menos em parte, as

\footnotetext{
${ }^{6}$ Recordamos o belo quadro In the Tepidarium, pertencente agora à Lady Lever Art Gallery, em Wirral (Liverpool), no Reino Unido, presentemente em exposição no Japão. Obra de 1881destinada à publicidade dos sabonetes Pears, foi então considerada demasiado ousada para o efeito.
}

Conimbriga, 55 (2016) 305-348 
linhas gerais desse relacionamento: a oposição latinidade-germanismo e o domínio de vastos territórios ultramarinos com relevante património romano, desde logo a Argélia (FIG. 6), cuja ocupação se iniciou em 1830. Desenvolveu-se assim um paradoxo identitário, não obstante o imaginário político-cultural afirmar permanentemente a latinidade francesa, que representaria a cultura latina por excelência, em oposição à realidade germânica, considerada de raiz bárbara e potencialmente perigosa. Quando se afirmava que os gauleses eram os antepassados dos Franceses modernos, remetia-se para segundo plano os Francos, inquestionavelmente germânicos. Esta atitude dúbia em relação às origens, redundante na história francesa, reflecte-se ainda a nível da cultura popular, como a famosa série de banda desenhada Astérix comprova, reflectindo a corrente celtizante de um discurso anti-histórico.

O imperador Napoleão III, sem desprezar a temática arqueológica gaulesa, dispensou grande atenção à época romana, envolvendo-se directamente em projectos de investigação, destacando-se o estudo do simbólico sítio de Alesia (Mont-Auxois) e apoiando escavações em Paris, facilitadas pelos grandes trabalhos de urbanismo desenvolvidos na cidade (Le Gall 1963 38-75; Eydoux 1965 7-55). O desfecho infeliz da guerra franco-prussiana em 1870 reforçou a atitude filo-romana da arqueologia francesa, representante de uma cultura defensora de valores opostos ao belicismo germânico ou assim considerada (GRACEFA 2008 83-104). Mas as ambiguidades vão persistir até aos nossos dias, com o regime de Vichy valorizando o passado galo-franco, servido em dado momento (1941-1942) por um ministro da educação especialista do mundo romano, Jérôme Carcopino ${ }^{7}$, ao qual se ficou a dever a organização administrativa da arqueologia francesa (CORCY-DEBRAY 2001), enquanto na V República o presidente Mitterrand num discurso pronunciado em Bibracte (Mont Beuvray) considerou ter decorrido naquele local o primeiro acto da história de França (FIG. 7), unindo-a inquestionavelmente ao passado gaulês (FLEURY-ILETTI 1996 196-197, 203-206).

Os aspectos coloniais da arqueologia francesa, sobretudo no Magrebe, merecem especial atenção, quer pela amplitude dos trabalhos desenvolvidos em Marrocos, na Argélia e na Tunísia, quer pelo facto

${ }^{7}$ Foi por iniciativa de Carcopino que o governo francês devolveu a Espanha a célebre Dama de Elche, comprada pelo Museu do Louvre através de uma intervenção de Pierre Paris. Solidariedade de regimes, mesmo na arqueologia, e neste caso muito favorável a Espanha.

Conimbriga, 55 (2016) 305-348 
de a França se ter considerado naqueles territórios como uma sucessora e continuadora directa da acção romana, o que não poucos investigadores magrebinos contemporâneos consideram uma atitude simplesmente colonialista, opinião pouco favorável à conservação conveniente do património arqueológico em questão (EN-NACHIONI 1995 161-170; ZAïD 2002 62-66). Fosse assim ou não, a verdade é que o investimento na investigação do passado norte africano teve resultados muito positivos, prejudicando mesmo o estudo do período romano na Metrópole ao desviar homens e meios para terras africanas Vejamos o que sobre estes trabalhos escreveu Ferreira de Castro: Pesquisas sobre pesquisas, congressos a seguir a congressos, chegaram arqueólogos de todas as partes do Mundo. Mas, em breve, eles sentiam bruxulear o seu entusiasmo, porque estas cidades das colónias romanas em África se pareciam umas com as outras, tanto, tanto, que, vista uma, dir-se-ia ter-se visto todas (CASTRO s/d 39). Sentimento parecido, agora suscitado pelas características pragmáticas da civilização romana foi expresso por Albert Camus, um desalentado pied noir (CAMus 1950 39).

Mas o que nos interessa, mesmo excluindo actos semelhantes ao beau geste do coronel Carbuccia, oficial da Legião Estrangeira e arqueólogo quando se lhe deparava a ocasião, prestando honras militares ao mausoléu de um comandante romano (CoMOR 1992 101-103), é o claro sentimento do direito francês à sucessão africana do Império Romano (FIG. 8), não apenas como herdeiros, mas como continuadores da mesma gesta latina (GreENHALGH 2014 32-37). Esta atitude esteve presente em muitas das obras publicados por arqueólogos franceses até aos finais da década de 50 do século passado, o que em nada lhes limitou o mérito científico, como se depreende daquilo que, numa grande síntese contrariando a opinião pessimista que referimos acima, nos ofereceu Gilbert Charles-Picard, da qual destacamos uma passagem plena de actualidade, embora referida aos homens da África romana: qui ont su tirer le meilleur parti d'une nature ingrate, et résoudre heureusement, pendant plusieurs siècles, les problèmes posés par l'antagonisme des races, des religions et des conditions sociales (CHARLES-PICARD 1959 iv-v). Sob a égide de Roma, naturalmente.

$\mathrm{O}$ recurso à arqueologia como suporte de ideias políticas é quase natural na Itália, mergulhada na nostalgia da grandeza perdida, como Dante evocava na Divina Comédia (DANTE 2.6.111), vigorosamente reflectida no jogo de contrastes presente na obra de Piranesi, nas vésperas de turbulências que marcariam o fim do Ancien Régime, tal como 
Bonaparte, discursando em Verona, apontava o célebre anfiteatro como exemplo dos tempos a construir, ao serviço de uma República que se inspirava romanticamente na Roma antiga (KocH 1946 21; Ferreira 1988 203-234). Foi sobretudo com o Fascismo que a arqueologia teve uma participação directa na luta política, através da qual se pretendia renovar a vida italiana e restaurar o Império, naturalmente numa óptica sobretudo colonial. Não havia, no caso italiano, qualquer contradição histórica e o apelo a um passado glorioso fazia sentido e tinha eco popular.

A cidade de Roma foi alvo de grandes trabalhos urbanísticos (FIG. 9), que não deixaram de causar alguns estragos ao património, mesmo de época romana, mas que permitiram conhecer e valorizar vastas zonas da cidade eterna, nomeadamente na área dos Foruns imperiais e do Mausoléu de Augusto (MANACORDA / TAMASSIA 1985; MoATTI 1989 45-52, 130-142), incluindo a construção de um museu para albergar a Ara Pacis nele reconstituída (Rossini 2006 108-125), por altura da comemoração do bimilenário do nascimento do imperador, em 1937. Nesse ano teve lugar uma grande exposição, a Mostra Augustea della Romanità, enquanto na preparação para a exposição internacional de 1942, impedida pela guerra, se efectuaram importantes escavações em Óstia, ainda que a sua metodologia fosse bastante descurada. O regime fez o possível para recuperar a simbologia romana, elegendo o fáscio dos litores romanos como emblema, sem esquecer a águia imperial, e o título Duce, do Latim Dux, para designar Mussolini, título imitado na Roménia pelo Conducator Antonescu e pelo Rais Nasser, no Egipto.

Como é evidente em tal contexto os arqueólogos foram levados a colaborar com a ideologia oficial. Foi notável a intervenção na Líbia, onde se desenvolveu uma mística do retorno de Roma cuidadosamente planeada e que foi acompanhada por numerosas escavações e restauros de monumentos romanos (FIG. 10), como em Leptis Magna e Sabratha (MunZI 2001; ZAFFIRI 2008). A grande estrada litoral então construída foi, a exemplo das vias romanas, denominada Via Balbia, do nome do governador Italo Balbo, na qual foi construído em 1937 um enorme arco, na fronteira entre a Tripolitânia e a Cirenaica, o Arco dei Fileni, destruído por ordem de Khadafi em 1973, em mais um dos muitos actos de apagamento da história contemporânea que se vão multiplicando pelo mundo. A inscrição que encimava o arco, extraída do Carmen Saeculare de Horácio, ilustrava, por si só, o programa ideológico do regime fascista e sua declarada inspiração no passado: Alme sol possis / nihil urbe Roma / visere maius (HorÁcIO C.S. 9-12). 
A fugaz conquista da Etiópia teve algum eco no revivalismo imperial fascista, cujos sonhos coloniais encontraram limitada margem de manobra, apesar da proclamação do Nuovo Impero Romano, como mostra a transferência para Roma, em 1937, de uma das grandes estelas de Axum, à imagem dos obeliscos egípcios transportados para a capital imperial, estela há pouco devolvida à origem pelo governo italiano. Que a história é feita também com vinganças, abrangendo com frequência a arqueologia, é uma verdade de todos os tempos, como prova, se tal fosse necessário, o triste final de uma das mais mediáticas acções da arqueologia italiana, a recuperação dos navios do Lago Nemi, uma complexa operação de arqueologia terminada em 1932. Esta magnífica realização, largamente propagandeada pelo regime, terminou tragicamente em 1944, quando os navios foram incendiados e destruídos no museu que os abrigava junto ao lago (MoretTi / CAPRINo 1957; MEIRAT 1964 154-159), tudo sugerindo tratar-se de um acto de vandalismo político contra um dos símbolos culturais do regime, concretizado apesar da indiscutível importância dos vestígios.

Analisar o problema da prática da arqueologia em regimes autoritários ou totalitários leva-nos, como é lógico, a verificar que só existe arqueologia alinhada com o pensamento oficial, dispensando medidas concretas de retaliação contra os que não concordarem com ele, sobretudo numa época em que a esmagadora maioria dos arqueólogos se encontrava vinculada a instituições estatais, antes do desenvolvimento da arqueologia empresarial, novidade que nem sempre os torna imunes à observação da vulgata oficial, quando existe, e a outro tipo de pressões. Parece-nos interessante, neste contexto sombrio, recordar algumas situações diferentes no âmbito do mesmo sistema político. $\mathrm{Na}$ desaparecida União Soviética e de uma maneira geral nos países do bloco de Leste, a doutrina oficial cultivou o princípio da existência do comunismo primitivo e a ideia estalinista de que o Império Romano caíra devido à revolta dos escravos, levando os arqueólogos a trabalhar longamente com esses dois fantasmas, o que não deixou de produzir interessantes resultados (Diakov/ Kovalev s/d 7-18; Kovalev s/d 3141, 459; RENFREW / BAHN 2000 471-472, 489-490), particularmente no campo do estudo da cultura material (KLEJN 1993), afinal o campo por excelência da Arqueologia. Foi manipulando dados desse tipo, propostos pelo arqueólogo polaco K. Jadzewski, que se afirmou a antiguidade da presença eslava numa zona que a ocidente se estendia quase até ao Elba, aproximando-se da fronteira da RDA, e a leste coincidia pratica- 
mente com o limite meridional do território russo de Kalininegrad (Königsberg), significativamente deixado de fora, circunstância que não permite dúvidas quanto a uma intenção política, destinada a justificar o mapa da região após 1945 (JoNes 1997 6-7).

A ideia da exploração dos oprimidos prevaleceu em toda a parte, mas é significativo verificar que, na Roménia de Ceaucescu, ilha de latinidade num mar de eslavos e magiares, a preocupação em comprovar uma identidade filiada na romanidade, de nítida expressão nacionalista, não só contribuiu para que a arqueologia do período romano tivesse relevo especial e os meios necessários numa sociedade parca de recursos, como levou os investigadores a desvios doutrinários, reconhecendo o carácter positivo do domínio romano na Dácia: Se poate spune că cei 165 ani de prezență efectivă a Romei în Dacia alcătuiesc o periodă historică dominată de febra construcţiilor. Din acest punt de vedere, oficialitatea romană continuase, la scară largă şi nivel superiior, politica de construcţii inaugurată de regii daci. Datorită acestei continuităţi, dar mai ales datorită imensului efort constructiv, caracterul spoliator al dominaţiei romane în Dacia este esenţialmente atenuat. In acelaşi sens pledează şi destinatia prin excelenţă publică, edilitară, culturală şi politică, de interes strict intern a majorităţii construcţiilor din oraşele daco-romane (BRANGA 1980 79). Na arqueologia "política" tudo é possível, mesmo, por vezes, reconhecer a verdade.

Um caso particularmente importante das relações entre a arqueologia e a ideologia é o da Alemanha nacional-socialista (ARNOLD 1990 464-478; MANTAS 2006 181-217; ChAPOUtot 2008). Embora o II Reich, criado em 1871, não tivesse problemas étnicos de maior importância foi dada especial atenção ao germanismo, em especial a ocidente do Reno e nos territórios limítrofes a populações eslavas. Naturalmente, o estudo da arqueologia clássica não teve uma participação significativa nesta questão, embora no quadro da educação literária as Humanidades tivessem uma presença relevante e o estudo da Antiguidade, nomeadamente através de trabalhos arqueológicos de vulto no Próximo Oriente, na Itália e na Grécia, alguns deles, como a escavação do santuário romano de Baalbek, no Líbano, apoiados pelo próprio Kaiser Guilherme II, tivesse particular importância. No ensino universitário a Pré-História tinha pouco prestígio, pois só em 1928 foi criada a primeira cátedra universitária da disciplina, mas começou a ganhar importância política logo em 1919, quando o difusionista Gustav Kossinna procurou demonstrar, através de dados arqueológicos, o direito alemão aos 
territórios cedidos à Polónia. Com o triunfo do Nacional-Socialismo em 1933 a situação mudou radicalmente. Entre 1933 e 1935 foram criadas oito cátedras universitárias de Pré-História (Urgeschichte) e, em 1933 e 1934, entre as personalidades distinguidas com o notável galardão que era o Adlerschild encontram-se um historiador e dois arqueólogos: Eduard Schwartz, Wilhelm Dörpfeld e Theodor Wiegand (FIG. 11).

Este reconhecimento, à escala nacional, do trabalho efectuado na área da Antiguidade pelos referidos investigadores, implicava não apenas uma consagração da história e da arqueologia alemãs, cuja excelência será frequentemente invocada em publicações de propaganda, nomeadamente naquelas destinadas ao estrangeiro (HERBERTMANN 1941 39), como implicava um convite tácito a que colaborassem activamente com o regime, como veio a acontecer. No âmbito da Kulturkampf desenvolvida pelo NSDAP, centrada em três princípios, Erde, Raum e Geist, o papel a que a arqueologia era chamada, não de uma forma subalterna, como tantas vezes sucede, mas de forma activa e estruturada, era essencial na definição de um espaço germânico cujas fronteiras, sempre indecisas ao longo da história (STÜRMER 2003 13-14; DirLMEIER 2014 11-18), deviam ser compreendidas como uma frente de colonização dinâmica. Se a tudo isto acrescentarmos a questão do arianismo compreenderemos facilmente a que pressões a arqueologia alemã esteve sujeita.

Para atingir os objectivos a que se propunham os responsáveis nacionais-socialistas reorganizaram a arqueologia, que ficou tutelada por duas entidades, entre as quais não faltaram atritos, a Amt Rosenberg, chefiada pelo ideólogo Alfred Rosenberg, e a Ahnenerbe, ligada à SS, sob controlo de Heinrich Himmler. Ambas as organizações dispunham de uma máquina editorial muito eficiente, destacando-se as suas publicações periódicas Germanenerbe e Die Kunde, para além de uma multidão de monografias, opúsculos e panfletos. A divulgação do passado germânico foi levada a todas as camadas da população, naturalmente de acordo com a versão politizada, estimulando-se a actividade de grupos de arqueólogos amadores, mais ou menos bem enquadrados, e as visitas de estudo. Entre os muitos nomes que contribuíram para este esforço devemos distinguir o de Hans Reinerth, figura principal da Amt Rosenberg até 1945, arqueólogo experimentado e que publicou no final da guerra uma obra fundamental para compreender os objectivos e métodos da organização (ReINERTH 1945). Não nos referimos 
à vertente esotérica ou simplesmente fantasista sobrevalorizando um passado germânico irreal, como o que se procurou nas escavações de Externsteine (FIG. 12), ou recorrendo a textos apócrifos, como a Crónica de Ura-Linda, por exemplo, passado vigorosamente defendido pelos chamados Germanomen (germanomaníacos), cujos excessos levaram a críticas por parte de altos dirigentes do NSDAP e do próprio Hitler (SPEER 1970 94-95).

Sublinhamos, porém, que se efectuaram excelentes escavações durante os anos da ditadura nacional-socialista, como as de Haithabu, Köln-Lidenthal ou Biskupin, rigorosas na metodologia, embora utilizadas como esteio de conclusões ideológicas, um método particularmente perigoso e eficiente, como se verifica na influência científica então exercida em muitos países (Clara / Ninhos 2014). Não olvidemos, pois aqui deparamos com alguma contradição essencial, a oposição que por vezes se fez sentir entre os arqueólogos pré-historiadores e os arqueólogos clássicos, oposição que não se tornou mais viva devido à evidente admiração de Adolf Hitler pela civilização greco-latina e à sua visão alargada do germanismo, como conceito fundacional (HITLER 1976 309), inspirada em Kossinna (Kossinna 1912). Esta admiração reflectia a preocupação de conseguir a fusão do germanismo com o classicismo, consagrada em muitas das expressões simbólicas do regime, particularmente na arquitectura e nas artes figurativas (FIG. 13), sem esquecer a cinematografia olímpica de Leni Riefenstahl (Graham 2001). Estamos, no conjunto, perante uma enorme reinterpretação da história e dos mitos, ao serviço de um novo ideário político, nascido das condições especiais da história alemã e das tragédias pessoais e colectivas resultantes da derrota de 1918. A arqueologia teve, como sempre acontece em países evoluídos, uma função a desempenhar, e desempenhou-a com eficiência alemã, nomeadamente fora do Reich, onde arqueólogos germânicos desenvolveram importantes projectos de investigação com apoio oficial, como aconteceu em Portugal com o casal Leisner entre 1943 e 1945 (BoAvENTURA / LANGLEY 2007 169-171).

Não podemos terminar, embora o fundamental já esteja demonstrado, sem referir algumas situações mais recentes de envolvimento da arqueologia em processos políticos, marcadamente nacionalistas, como vem acontecendo na China desde meados do século passado, com tendência para se intensificar no quadro de afirmação global desta potência, não faltando agora debates apaixonados sobre a identidade chinesa (Lewis 2016). Devemos sublinhar que a gravidade de algumas situa-

Conimbriga, 55 (2016) 305-348 
ções que se verificam presentemente é de tal ordem que justifica uma análise específica que procuraremos fazer oportunamente. Referimo-nos, naturalmente, à catástrofe que se abateu sobre os sítios arqueológicos do Iraque e da Síria, alvos preferenciais, pelo que de simbólico representam no imaginário ocidental e pelo valor que lhes é atribuído pelos governos locais, por razões históricas ou económicas. Para além de todas as razões que possam ser avançadas devemos entender que, para quem os destrói, os monumentos não têm qualquer interesse patrimonial, situação que o historiador Ibn Khaldun caracterizou no século XIV, quando aludiu às consequências negativas das invasões árabes (IBN KHALDUn 1967 4.24-25). Devemos, todavia, distinguir, embora nem sempre seja possível fazê-lo, entre danos colaterais e a destruição voluntária de património arqueológico, por razões vagamente ideológicas, como vai sucedendo todos os dias no Iraque, na Síria e na Líbia, e já sucedeu no Líbano, no Afeganistão e no Mali. O cenário geral não é de molde a suscitar optimismos.

São estas situações que nos levam a considerar de forma muito renitente a política de devolução de objectos arqueológicos presentemente conservados em museus ocidentais. Mesmo em países nos quais, apesar de tudo, a desordem ainda não se estabeleceu, como o Egipto, onde Zahi Awass, excelente representante do star system que invadiu a arqueologia, desenvolveu uma truculenta campanha a favor da devolução de peças expostas em museus europeus, os sítios arqueológicos são potenciais locais de atentados ou de agressões. Basta recordar a desordem que vitimou o secular Institut d'Égypte (FIG. 14), incendiado em 2011 (Downs 2012 5-6), ano em que não faltaram assaltos a diversos museus, permitindo todos os receios em relação ao futuro ${ }^{8}$. Naturalmente que a arqueologia surge em tais contextos como vítima, não como cúmplice, não só por se tornar impossível a investigação no terreno, como por se assistir à destruição de monumentos e de equipamen-

${ }^{8}$ As situações de instabilidade facilitam incidentes e acidentes, como o sucedido no Museu do Cairo (em Outubro de 2014?) com a máscara funerária do faraó Tutankamon, cuja barba cerimonial, solta por motivo desconhecido, foi "restaurada" de forma expedita, com evidente prejuízo para a peça. Os assaltos a museus, como o de Malawi, em al-Minya, ocorrido em Agosto de 2013, terão como motivo principal o roubo, a que se junta a destruição gratuita. Na Síria e no Iraque as escavações clandestinas tornaram-se regra, e os assaltos a museus, como o de Alepo, normais e nem sempre da iniciativa dos jihadistas.

Conimbriga, 55 (2016) 305-348 
to fundamentais, como museus, bibliotecas e laboratórios. A destruição de monumentos por razões pretensamente religiosas ocorre agora com grande frequência, não tendo o conhecido caso dos Budas de Bamiyan, demolidos pelos talibã afegãos em 2001, sido suficiente para acautelar as situações dramáticas que se vão repetindo no Iraque e na Síria, só passíveis de solução manu militari, concretizada noutras circunstâncias.

Infelizmente, a incapacidade revelada para preservar sítios arqueológicos que se situam entre os mais importantes da história da civilização, particularmente numerosos na região, parece revelar cruamente a impotência de organizações como a Unesco em gerir situações que conduziram ao massacre das ruínas de Mari, Hatra, Doura-Europos, Apameia e a muito simbólica Palmira (Tadmor), entre tantas outras, sem falar aqui, por exemplo, da importante biblioteca de Mossul, no Iraque, incendiada. Não faltaram denúncias ignoradas, na altura própria, como a do intelectual libanês Hassan Hamadé (HAMADÉ 2015). Na verdade, é mais fácil multiplicar a classificação de sítios, onde muitas vezes a motivação económica parece dominante, que obter os acordos políticos necessários para implementar intervenções no terreno, única forma de travar as acções terroristas que tomam o património arqueológico, mais uma vez considerado símbolo de um passado a obliterar, como objectivo primordial, pois é rentável tanto em termos de impacte moral como através do espólio de antiguidades destinadas ao mercado clandestino, que às vezes não o é tanto como se pensa.

A intervenção da ONU nesta tragédia parece-nos particularmente frouxa, permitindo dúvidas fundadas quanto à sua eficiência, tal como existe, face aos problemas do século XXI, tão longe daquilo que muitos sonhadores distraídos idealizaram. Para complicar mais a questão parece haver um esforço em centrar as atenções em Palmira, e mesmo aqui sobretudo no arco de triunfo, desviando-as de outros sítios também maltratados, com a agravante de se pretender divulgar a ideia de que as destruições perpetradas na cidade não foram tão graves como se temia, o que, no mínimo, nos parece inaceitável (FIG. 15). Seja como for, a utilização ideológica do sucedido ganhou já expressão no Ocidente, com a construção de uma réplica do arco de triunfo, exposta em Londres e posteriormente em Nova Iorque, o que sugere interesses económicos sob a necessidade dos trabalhos de recuperação dos sítios atingidos. A rapidez com que se aparenta actuar depois da recuperação da cidade pelas forças governamentais contrasta claramente com a ineficácia e os

Conimbriga, 55 (2016) 305-348 
silêncios ambíguos que se verificaram em 2015, quando tudo indicava o que iria suceder?.

Quanto à Europa e ao que aqui sucedeu durante a Segunda Guerra Mundial nem vale a pena sequer considerá-lo neste momento, desde que reconheçamos que as culpas cabem aos dois lados, continuando as demolições programadas ainda muitos anos depois do final do conflito, inclusive na Alemanha, com o evidente intuito de apagar a memória (KRIER 1983 33-38). Nas hostilidades que abalaram a ex-Jugoslávia não faltaram destruições quase sempre voluntárias de monumentos, entre os quais se devem recordar numerosas mesquitas e igrejas antigas. Muito conhecido é o caso da bela ponte bósnia de Mostar (DodDs 1998 2-9), monumento otomano que deu o nome à cidade de que é o símbolo por excelência, circunstância que levou à sua destruição ${ }^{10}$. Razões menos bélicas, políticas ou económicas, mas igualmente destrutivas, também não faltam, como no caso do arrasamento do forte otomano de al-Ajyad em Meca, substituído por um complexo comercial e habitacional avaliado em 533 milhões de dólares.

Um caso interessante é o de Israel, onde a investigação arqueológica remonta ao século XIX, inicialmente efectuada no quadro internacional da Arqueologia Bíblica e mais tarde por iniciativa de sociedades judaicas. Com a formação do Estado de Israel, em 1948, desenvolveu-se intensa actividade arqueológica, que depois da guerra de 1967, se alargou ao Sinai e a outras áreas passadas ao controlo israelita. É inegável que a busca de vestígios da Antiguidade judaica, ditada pela necessidade de afirmar a sua presença no território que para muitos era, há séculos, a Palestina, teve consequências muito positivas do ponto de vista do conhecimento da região e valorizou significativamente o seu património arqueológico. É evidente que a arqueologia teve fortes condicionalismos ideológicos e tem gozado de apoios que noutras circunstâncias dificilmente seriam possíveis, envolvendo-se de vez em quando em problemas de difícil solução, caso, por exemplo, das escavações em

${ }^{9}$ É, no mínimo, curiosa a atitude de apoio ao regime sírio expressa um pouco por todo o lado, apenas depois da reconquista de Palmira. Grande parte deste apoio teria sido muito mais útil em Maio de 2015, quando não faltaram críticas abertas à actuação da directora-geral da UNESCO, Irina Bukova. Havia que optar entre ficções políticas e a realidade no terreno, como tantas vezes acontece, o que exige grandes líderes.

${ }^{10}$ A ponte foi entretanto reconstruída, com uma inauguração de pompa e circunstância em 2004.

Conimbriga, 55 (2016) 305-348 
torno da plataforma do Templo construído por Herodes, sobre a qual se encontra o Haram al-Sharif.

Um sítio cuja escavação teve uma forte carga simbólica, emocional e política é o do palácio-fortaleza de Massada (YADIN 1966), perto do Mar Morto, impressionante construção de Herodes onde decorreu um dos dramas finais da Grande Revolta judaica do século I, em 73-74, de acordo com o relato de Flávio Josefo segundo o qual os defensores preferiram suicidar-se em massa a entregar-se às forças romanas. Desta forma, Massada ocupa um lugar especial no imaginário israelita, como sítio de peregrinação e de exemplo (FIG. 16), apesar de algumas das conclusões de Yigael Yadin presentemente suscitarem justificada discussão (Ben-Yehuda 2002). Em Massada desenvolveram-se importantes escavações, com projecçção internacional, mas os campos romanos da circunvalação não foram ainda alvo da investigação que merecem. Outro sítio também ligado à revolta, Gamla, nos Montes Golan, foi escavado em condições muito difíceis (GUTMAn 1981 30-34), confirmando o indiscutível interesse israelita pela arqueologia, ainda que, como nos casos referidos, envolva intuitos que frequentemente ultrapassam o campo meramente científico.

A ideologia, no mundo globalizado, tem ganho outro tipo de motivações, embora nos pareça que haja algum exagero nesta ideia muito difundida, destacando-se as de tipo económico e político, normalmente comprometidas. Há, pois, situações envolvendo atentados patrimoniais que não podem ser imputados a razões ideológicas, como tem sucedido em Istambul, por exemplo, ou com a construção de numerosas barragens em zonas de grande interesse arqueológico (KENNEDY 1998 20-27; RonDOT 2014 26-29), sem intervenções semelhantes às que se efectuaram no Egipto por altura da construção da grande barragem de Assuão, ainda assim desastrosa para o património arqueológico (SAUNERON 1968 30-40). Caso muito interessante, e sobre ele já se disse tudo, ou talvez não, é o do projecto de construção da barragem do Côa, que claramente se politizou por acção dos arqueólogos, num momento conveniente, levando à sua suspensão (JoRGE 1995 313-866), circunstância invulgar e que parece confirmar que, em Portugal, a comunidade dos pré-historiadores mantém uma situação dominante quando comparada com a dos restantes arqueólogos, talvez por estes se encontrarem mais condicionados pela história.

A imagem do mundo entregue aos efeitos perversos da globalização e a um péssimo entendimento do multiculturalismo, tão frequente- 
mente ideológico e alheio ao que é verdadeiramente comum à humanidade, não nos deixa tranquilos quanto ao futuro. Os arqueólogos devem estar preparados, e se possível unidos, para compreenderem e enfrentarem desafios complicados, afastando-se desde já das ilusões que tantas vezes têm acarinhado, sobretudo quando procuram uma função social para a arqueologia (WiTLHEY 1986 200-214). Continuaremos a assistir à destruição de sítios e de equipamentos científicos por diversas razões, em muitos casos sem qualquer tentativa de cosmética economicista ou ideológica, por simples estupide $\mathrm{z}^{11}$, assim como haverá sempre profissionais, académicos ou não, dispostos, por esta ou por aquela razão, a sustentar ou a facilitar práticas marginais.

O século XXI, herdeiro de conflitos antigos e criador de outros novos, continuará a envolver os arqueólogos em situações difíceis, porque não podem isolar-se da sociedade em que vivem e trabalham. Os arqueólogos, ou pelo menos a esmagadora maioria, não são saudosistas, políticos ou promotores turísticos, são cientistas e como tal devem assumir essa condição, reconhecendo todas as dificuldades que ela implica, condição em tudo alheia ao tipo Indiana Jones, embora nestas aventuras cinematográficas haja muita política. Que a arqueologia vai continuar na linha da frente da construção ou reconstrução de identidades num mundo de fronteiras indecisas e de escolhas permanentes, deduz-se, se tal fosse necessário, da afirmação do subsecretário dos negócios estrangeiros italiano durante a inauguração, em 2009, da exposição comemorativa da devolução da estela de Axum à Etiópia: É através de símbolos e da reconstituição de símbolos que a identidade de uma nação pode ser construida (MANTICA 2009). Grande verdade, onde desde sempre os mitos se afirmam (CALAME 2015 349-355), mas diremos que a destruição de símbolos tem uma função não menos importante, hoje como ontem, pois a Civilização muda, mas o Homem não ${ }^{12}$, o que se torna evidente nesta época em que se concretizam os receios de Huxley e de Orwel, longe dos sonhos de Volney quando, nas vésperas da Revolução Francesa reflectiu sobre o destino das sociedades humanas, no cenário fantástico das ruínas da inesquecível Palmira (VoLNEY 1960 21-27).

\footnotetext{
${ }^{11}$ Recordamos a destruição em Paris, em Maio de 1968, da grande maqueta de Roma, da autoria de Paul Bigot, que existia na Sorbonne, lamentável facto comprovativo de que a estultícia é uma realidade universal.

${ }^{12}$ Agradecemos cordialmente ao Dr. Luís Madeira a preparação das figuras deste artigo.
}

Conimbriga, 55 (2016) 305-348 


\section{BIBLIOGRAFIA}

Alarcão, J. de (1997), “A arqueologia contextualista", Mathésis 6 11-32.

Alarcão, J. de (2000), A escrita do tempo e a sua verdade (ensaios de epistemologia da arqueologia), Coimbra.

AnaCleto, R. (coord.), (1994), O neomanuelino ou a invenção da arquitectura dos Descobrimentos, Lisboa.

Arnold, B. (1990), "The Past as Propaganda: totalitarian archaeology in Nazi Germany", Antiquity 64 464-478.

Atard, V. P. (1971), El arco de triunfo en la Ciudad Universitaria, Madrid.

Barros, T. de (s/d), História de Portugal. Ensino Primário [28 ed.], Porto.

Ben-Yenuda, N. (2002), Sacrificing Truth. Archaeology and the Mith of Masada, Amherst (NY).

BoARDMAN, J. (1964), Greek Art, Londres.

Boaventura, R. / Langley, M. (2007), "Georg Leisner (1870-1957): Determinação na busca do Megalitismo ibérico", O Arqueólogo Português (4ª́rie) 25 167176.

Boule, P. (s/d), O planeta dos macacos, Lisboa.

Bradford, J. (1957), Ancient Landscapes. Studies in Field Archaeology, Londres.

Branga, N. (1980), Urbanismul Daciei romane, Timisoara.

Breton, J.-J. (2010), Anthologie des peintres pompiers, Bordéus.

Bruno, G. [Augustine Foulllée] (1877), Le tour de France par deux enfants, Paris.

Calame, C. (2015), Qu'est que la mythologie grecque?, Paris.

Camus, A. (1950), Noces, Paris.

Castro, F. de (s/d), A volta ao mundo, 1, Lisboa.

Chapoutot, V. (2008), Le national-socialisme et l'Antiquité, Paris.

Christie, A. (2010), Na Síria. Conta-me lá como vives, Lisboa.

Clara, F. / Ninhos, C. (eds), (2014), A Angústia da Influência. Política, Cultura e Ciência nas Relações da Alemanha com a Europa do Sul, 1933-1945, Frankfurt am Main.

Comor, A. (1992), La Légion Étrangère, Paris.

Corcy-Debrai, S. (2001), Jérôme Carcopino. Un historien à Vichy, Paris.

Côrrea, M. (1924), Os povos primitivos da Lusitânia, Porto.

COWPER, W. (1818), The minor Poems of William Cowper of the Inner Temple, Londres.

Dante Aliguieri (2011), A Divina Comédia (trad. V. G. Moura), Lisboa.

Diakov, V. / Kovalev, S. (s/d), História da Antiguidade Oriental, Lisboa.

Diakov, V. (s/d), História de Roma, Lisboa.

DiAZ-Andreu, M. / RAmíreZ-SÁnCheZ, M. (2007), “Archaeological resource management under Franco's Spain: The Comisaria General de Excavaciones Arqueológicas", in Archaeology under Dictatorship, Nova Iorque.

DirlmeIER, U. et alii (2014), História Alemã, Lisboa.

Dodds J. (1998), "Hearts and stones", Aramco World 49 (5) 2-9.

Downs, J. (2012), "Calamity in Cairo", History Today 62 5-6.

Conimbriga, 55 (2016) 305-348 
ENCARNAÇÃo, J. d' (1993-1994), "No centenário da publicação das Religiões da Lusitânia: nacionalismo em Leite de Vasconcelos", O Arqueólogo Português (4 ${ }^{\mathrm{a}}$ série) 11-12 35-42.

En-NaChioni, E. (1995), "Las primeras excavacionees en Volubilis (Marruecos) arqueología, historia o simple colonización?”, Pyrenae 26 161-170.

Eydoux, H.-P. (1965), Promenades dans la France antique, Paris.

FABIÃo, C. (1996), "Archaeology and Nationalism: the Portuguese Case", in Nationalism and Archaeology in Europe, Londres 90-107.

Ferreira, J. R. (1988), "Grécia e Roma na Revolução Francesa”, Revista de História das Ideias 10 203-234.

Fleury-ILETti, B. (1996), "The identity of France: archetypes in Iron Age studies", in Cultural Identity and Archaeology. The Contruction of European Communities, Londres 196-208.

Garelli, P. (1971), L'Assyriologie, Paris.

Gracefa, A. (2008), “Antiquité barbare, l'autre Antiquité: l'impossible réception des historiens français (1800-1950)", Anabases. Traditions et Réceptions de l'Antiquité 8 83-104.

Graham, C. (2001), Leni Riefenstahl and Olympia, Lanham.

Graves-Brown, P. / Jones, S. (eds), (1996), Cultural Identity and Archaeology. The Construction of European Communities, Londres.

Greenhalgh, M. (2014), The Militar and Colonial Destruction of the Roman Landscape of North Africa, Leida.

GuHA, S.(2003), "Imposing the Habit of Science: Sir Mortimer Wheeler and Indian Archaeology", Bulletin of the History of Archaeology 13 (1) 4-10.

Guerra A. / Fabĩ̃o, C. (1992), "Viriato. Genealogia de um mito", Penélope 8 9-23.

Gutmann, S. (1981), "The Synagogue at Gamla”, in Ancient Synagogues Revealed, Jerusalém.

Hamadé, H. (2015), “Madame Bokova, Palmyre, Sana'a et Ninive exigent votre démission", www.voltairenet.org/article187926.html [consultado a 20.6.2015].

Herbertmann, M. (1941), Cartilha da Grande Alemanha, Berlim.

Hitler, A. (1976), Mein Kampf. A minha luta, Lisboa.

Holanda, F. de (1984), Da fábrica que falece à cidade de Lisboa (ed. J. F. Alves), Lisboa.

Horácio (1917), Horatius Carmina (ed. Fr. Vollmer), Lípsia.

HouellebecQ, M. (2015), Submissão, Lisboa.

Huxtable, A. L. (1963), "Farewell to Penn Station", The New York Times, 30.10.63.

IBN Khaldun(1967), An Introduction to History. The Muqqadimah (trad. F. Rosenthal), Londres.

Jones, F. H. (2008), Tirocinium Imperii: Public School Education in Victorian Era, the Classical Curriculum and the British Imperial Ethos, Middleton (Conn.).

Jones, S. (1997), The Archaeology of Ethnicity. Constructing Identities in the Past and Present, Londres.

Conimbriga, 55 (2016) 305-348 
Jorge, V. O. (ed.) (1995), “Actas do $1^{\circ}$ Congresso de Arqueologia Peninsular”, Trabalhos de Antropologia e Etnologia 35 (4) 311-896.

JÜNGER, E. (1995), Sobre as falésias de mármore, Lisboa.

Kennedy, D. (1998), "Drowned cities of the Upper Euphrates", Aramco World 49 (5) 20-27.

KIPLING, R. (1906), Puck of Pook's Hill, Toronto.

Klejn, Leo (1993), La arqueología soviética. Historia y teoría de una escuela desconocida, Barcelona.

Косн, Н. (1946), Arte romano, Barcelona.

Kossina, G. (1912), Die Deutsche Vorgeschichte: eine Hervorragend Nationale Wissenschaft, Lípsia.

Krier, L. (1983), “Krier on Speer”, Architectural Review 173 33-38.

Le Gall, J. (1963), Alésia. Archéologie et histoire, Paris.

Lewis, R. (2016), “Does Chinese Civilization come from Ancient Egypt?”, www.foreignpolicy.com/2016/09/02 [consultado a 10.9.16]

MACK, J. (1998), A Prince of our Disorder. The Life of T. E. Lawrence, Cambridge (MA).

Manacorda, D. / TAMassia, R. (1985), Il picone del regime, Roma.

Mantas, V. G. (2006), “Arqueologia e ideologia. O caso germânico", Revista Portuguesa de História 38 181-217.

Mantas, V. G. (2007), “Arqueologia, Ciência e Cultura”, Rua Larga 1533.

Mantas, V. G. (2008), “O valor da ruína”, Biblos (nova série) 6 147-192.

Mantas, V. G. (2008a), “A exposição napolitana Alma Tadema e la nostalgia dell'Antico", Boletim de Estudos Clássicos 50 71-78.

Mantas, V. G. (2012), As vias romanas da Lusitânia, Mérida.

Mantas, V. G. (2012a), "O legado histórico romano e a crise do Ocidente contemporâneo", Biblos (nova série) 10 47-73.

ManticA, A. (2009), whc.unesco.org/en/news/567 [consultado em 20.1.2014].

Marco, F. / Abásolo Álvarez, J. A. (1995), Tipología y iconografía en las estelas de la mitad septentrional de la Península Ibérica, in Nacimiento de la Cultura Epigráfica en Occidente, Saragoça 327-359.

Matos, S. (1993-1994), "Leite de Vasconcelos no debate acerca da formação de Portugal: um confronto com Oliveira Martins", O Arqueólogo Português ( $4^{\mathrm{a}}$ série) 11-12 11-33.

Mattingly, D. J. (ed.), (1997), Dialogues in Roman Imperialism. Power, discourse and discrepant experiences in the Roman Empire, Portsmouth (RI).

Maugham, S. (s/d), Biombo chinês. Contos, Lisboa.

Meirat, J. (1964), Marines antiques de la Mediterranée, Paris.

MoATti, C. (1989), À la recherche de la Rome antique, Paris.

Moffat, A. (2005), Before Scotland: the Story of Scotland Before History, Londres.

Moreti, G. / CAPrino, C. (1957), Il Museo delle navi romane di Nemi, Roma.

Moscati, S. (1963), L'Orient avant les Grecs, Paris.

Munzi, M. (2001), L'epica del ritorno: arqueologia e politica nelle Tripolitania italiana, Roma.

Conimbriga, 55 (2016) 305-348 
Murphy, C. (2007), Are we Rome? The Fall of an Empire and the Fatte of America, Boston-Nova Iorque.

Oliveira, A. (2004), "O pensamento do imaginário lusitano nas obras dos arquitectos portugueses do século XX", A Obra Nasce. Revista de Arquitectura e Urbanismo da Universidade Fernando Pessoa, 0 40-56.

PAço, A. do (1965), Escavações de carácter histórico realizadas no campo de batalha de Aljubarrota, Braga.

Pearson, M. L. (2008), Perils of Empire: The Roman Republic and the American Republic, Nova Iorque.

Picard, G.-C. (1959), La civilisation de l'Afrique romaine, Paris.

Piggott, S. (1977), "Robert Eric Mortimer Wheeler", Biographical Memoirs of Fellows of the Royal Society 23 623-642.

Polo, F. (2009), "El estudio de la Historia Antigua en España bajo el Franquismo", Anales de Historia Antigua, Medieval y Moderna 41 3-10.

Polo, F. (2014), "Héroes suicidas: la Iberiké de Apiano y la creación de mitos del nacionalismo español", in Miscelânea de Estudios en Homenaje a Guillermo Fatás Cabeza, Saragoça 571-578.

Pseudo-Platão (1970), Épinomis (trad. L. Robin), Paris.

ReINHERT, H. (1945), Vorgeschichte der deutschen Stämme: Germanische tat und Kultur auf deutschem Boden, I-III, Berlim.

Renfrew, C. / Bahn, P. (2000), Archaeology: Theories, Methods and Practice, Nova Iorque.

Resende, A. de (2006), As antiguidades da Lusitânia (ed. Rosado Fernandes), Coimbra.

Richter, T. (2008), "Espionage and Near Easter Archaeology: a historiographical survey", Public Archaeology 7 (4) 212-240.

Pereira, M. H. Rocha, (2008), Raízes clássicas da União Europeia, Boletim da Faculdade de Direito 4 11-24.

Rondot, V. (2014), "L'archéologie de sauvetage avant la mise en eau de grands barrages: l'exemple de la Nubie Sudanaise", Rayonnement du CNRS 64 26-29.

Rose, G. (1995), "Place and Identity: a sense of place", in A Place in the World? Places, Cultures and Globalization, Oxford 88-132.

Rossini, O. (2006), Ara Pacis, Roma.

Rowlands, M. (1994), "The politics of identity in archaeology”, in Social Construction of the Past. Representation as Power, Londres 129-143.

Ruiz Zapatero, G. R. (1996), "Celts and Iberians. Ideological manipulation in Spanish archaeology", in Cultural Identity and Archaeology. The Construction of European Communities, Londres 179-195.

Satia, P. (2008), Spies in Arabia. The Great War and the Cultural Foundations of Britain's covert Empire in the Middle East, Oxford.

SAuneron, S. (1968), L'Égyptologie, Paris.

Schwartz, D. / Zhewen, L. (2000), The Great Wall of China, Londres.

Sealey, P. R. (1997), The Boudican Revolt Against Rome, Princes Risborough.

SpeER, A. (1970), Inside the Third Reich, Nova Iorque.

Conimbriga, 55 (2016) 305-348 
Stürmer, M. (2003), O Império Alemão, Lisboa.

Swanson, V. (1977), Alma-Tadema: The Painter of the Victorian Vision of the Ancient World, Londres.

TAYLOR, B. (1995), "Amateurs, professionals and the knowledge of archaeology", The British Journal of Sociology 46 (3) 499-509.

Villaverde Vega, N. (2001), La Mauritania Tingitana en la Antigüedad Tardía (siglos III-VII), Madrid.

Vivar, F. (2000), “El ideal 'Pro Patria Mori’ en La Numancia de Cervantes”, Cervantes 20 (2) $7-30$.

Volney, C. de [Constantin de Chasseboeuf] (1960), As ruínas de Palmira. Meditação acerca da destruição dos impérios (trad. F. Quintal), Lisboa.

Ward-Perkins, B. (2003), A queda de Roma e o fim da civilização, Lisboa.

Whittley, A. (1986), "Archaeological and Social Sciences: why they should not be integrated", Archaeological Review 5 206-214.

Wilkinson, J. (1978), Jerusalem as Jesus knew it. Archaeology as Evidence, Londres.

Winstone, H. F. (2004), Gertrude Bell: A Biography, Londres.

Woolf, V. (2012), Noite e dia, Lisboa.

YAdin, Y. (1966), Masada. La dernière citadelle d'Irsräel, Paris.

ZAFFIRI, G. (2008), L'impero que Mussolini sognava per l'Italia, Nápoles.

ZAïD, N. (2002), “Un nouvelle élan pour l’Algèrie romaine”, Archéologia 387 62-66.

Conimbriga, 55 (2016) 305-348 


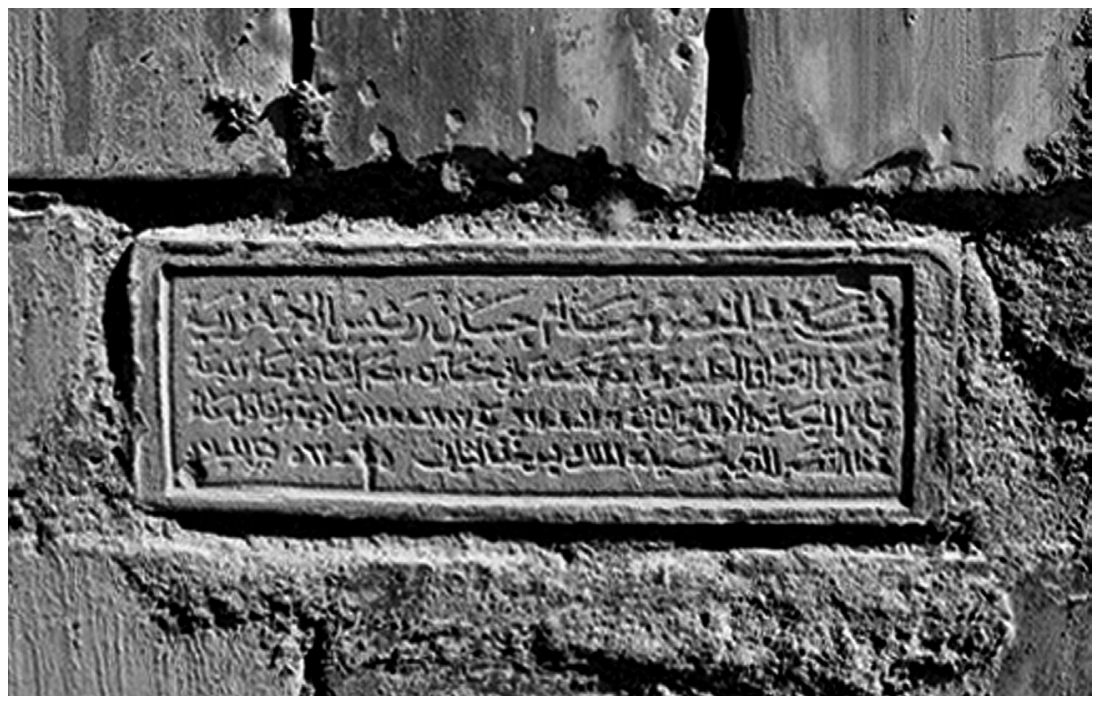

FIG. 1 - Tijolo com inscrição comemorando a reconstrução de Babilónia por Saddam Hussein. (Foto: Osama Amin).

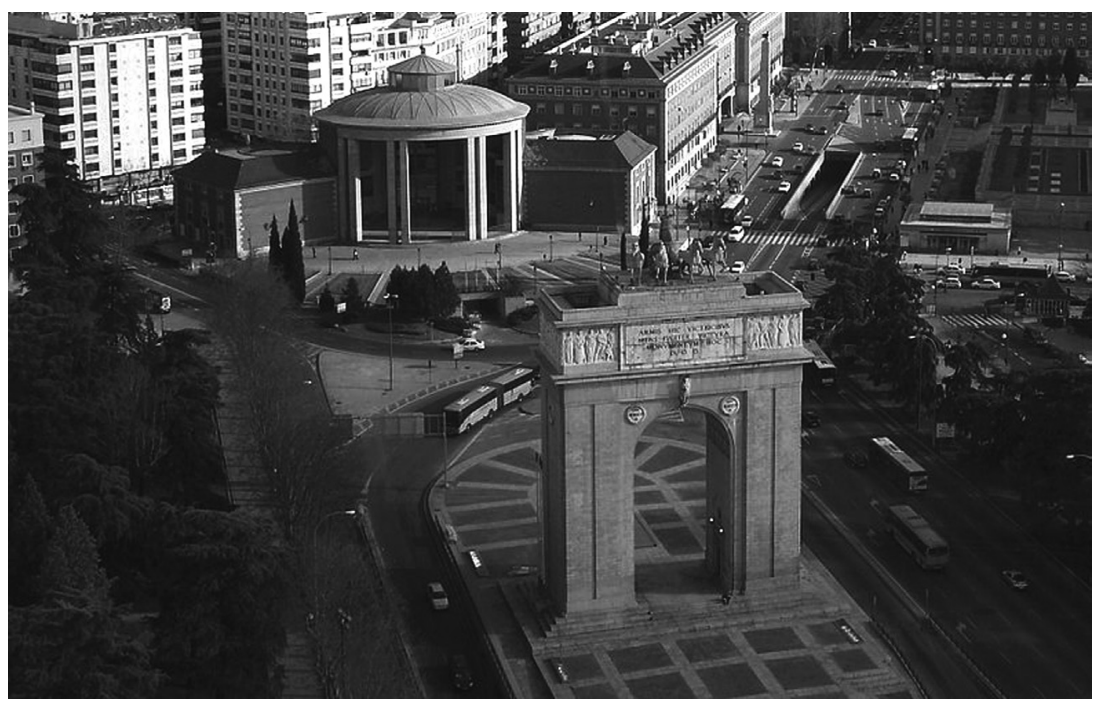

Fig. 2 - O Arco de la Victoria e o Templete a los Caídos, actualmente edificio administrativo, em Madrid. 


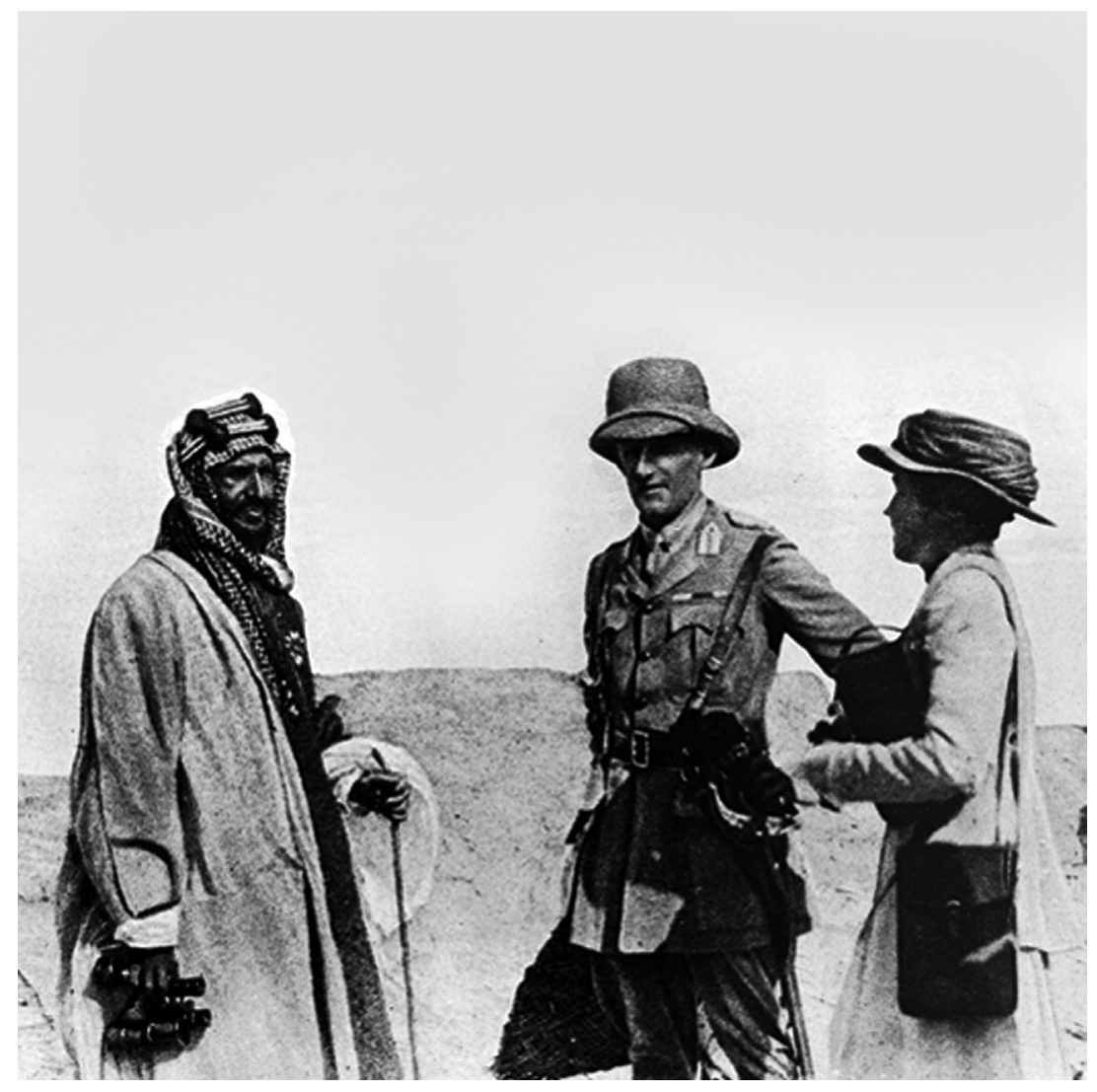

Fig. 3 - Gertrude Bell em 1916, em Bassorá, com o rei Ibn Saud e o general britânico Percy Cox. (Newcastle University Library). 


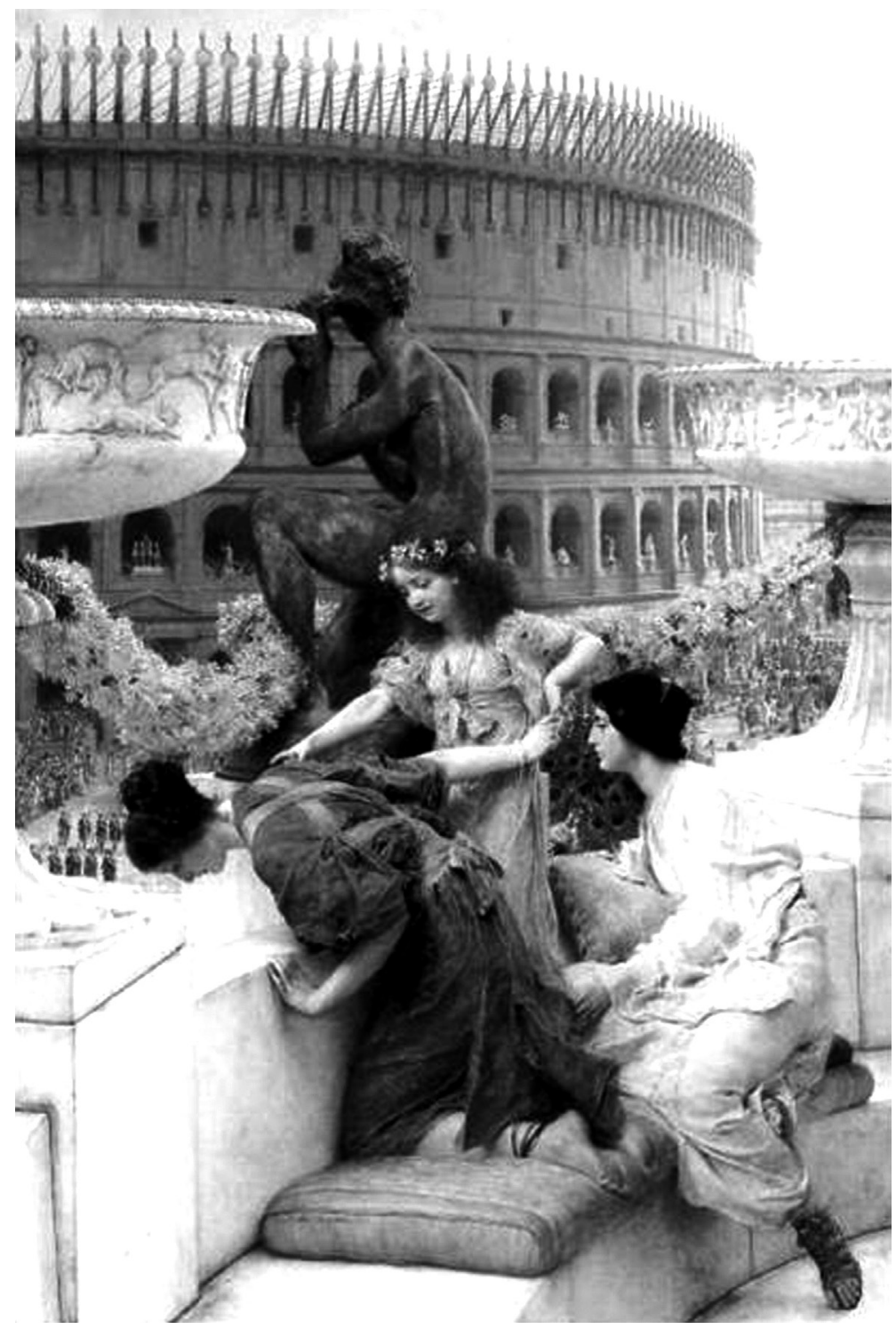

FIG. 4 - Lawrence Alma-Tadema, The Colosseum, pintura de 1896 (colecção privada). 


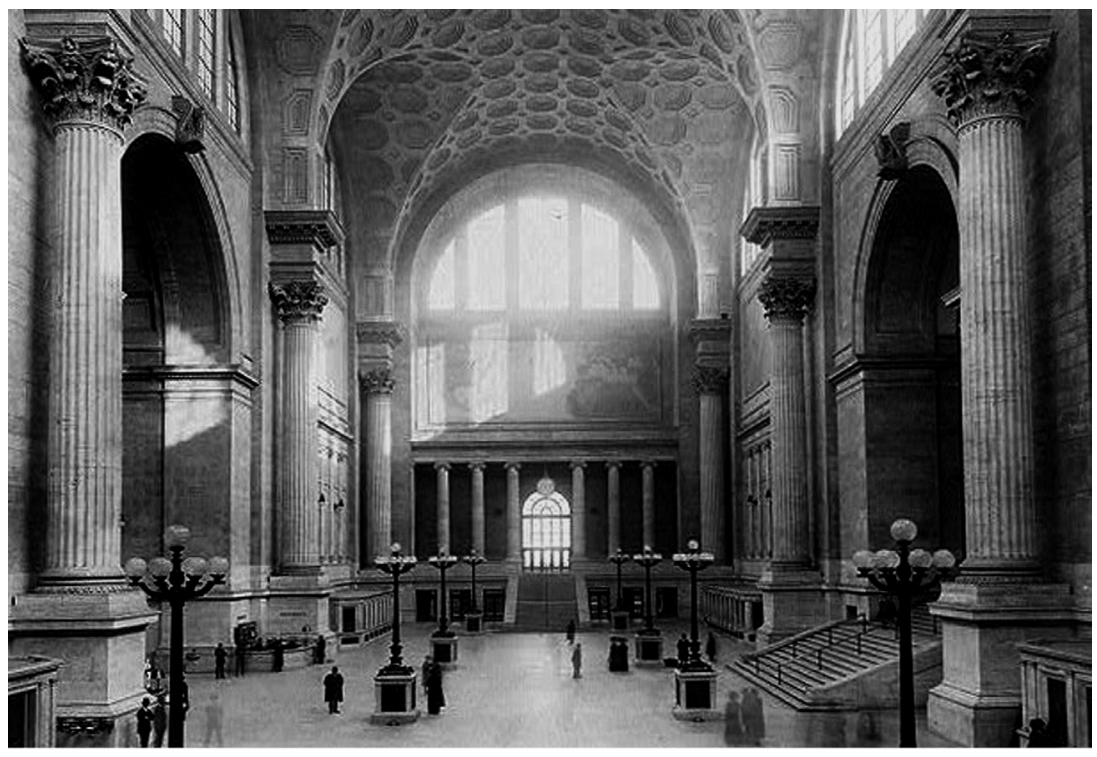

Fig. 5 - O átrio principal da Pennsylvania Station de Nova Iorque, em 1911 (Library of Congress).

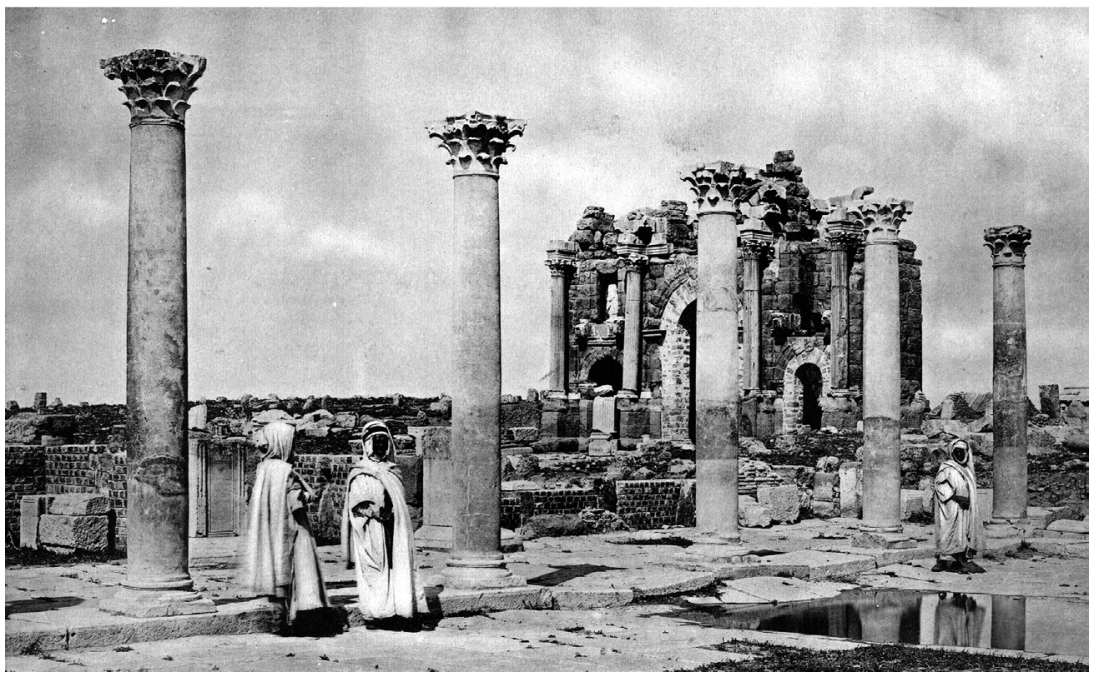

Fig. 6 - As ruínas de Timgad (Thamugadi), na Argélia, em 1900 (Foto: Mieusement). 


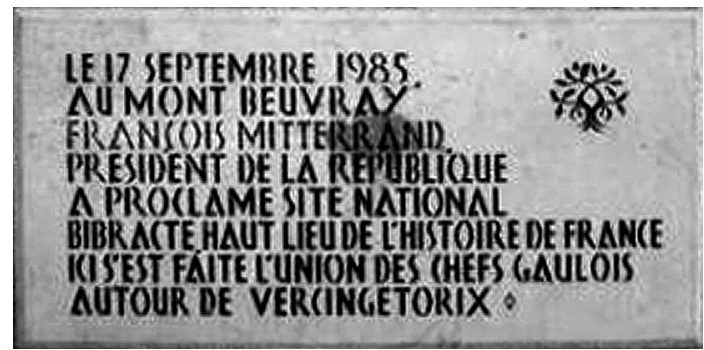

FIG. 7 - Placa no Mont Beuvray recordando o discurso de François Mitterrand. (Foto: V. Mantas).

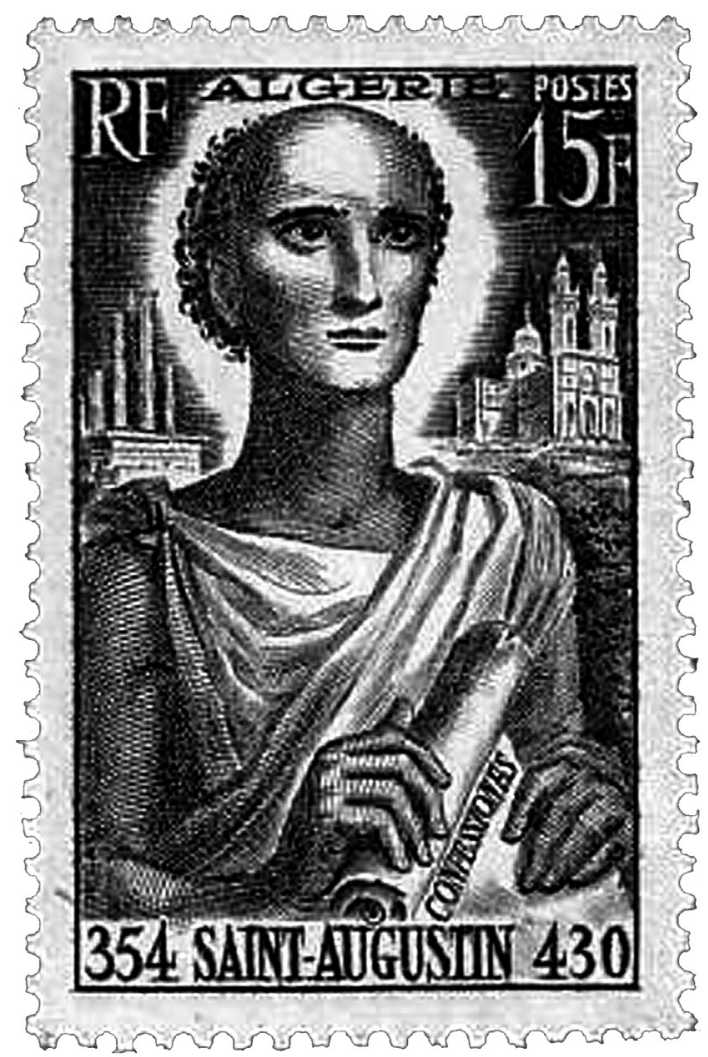

Fig. 8 - Selo de correio da Argélia francesa recordando Santo Agostinho, bispo de Hipona (Annaba). 


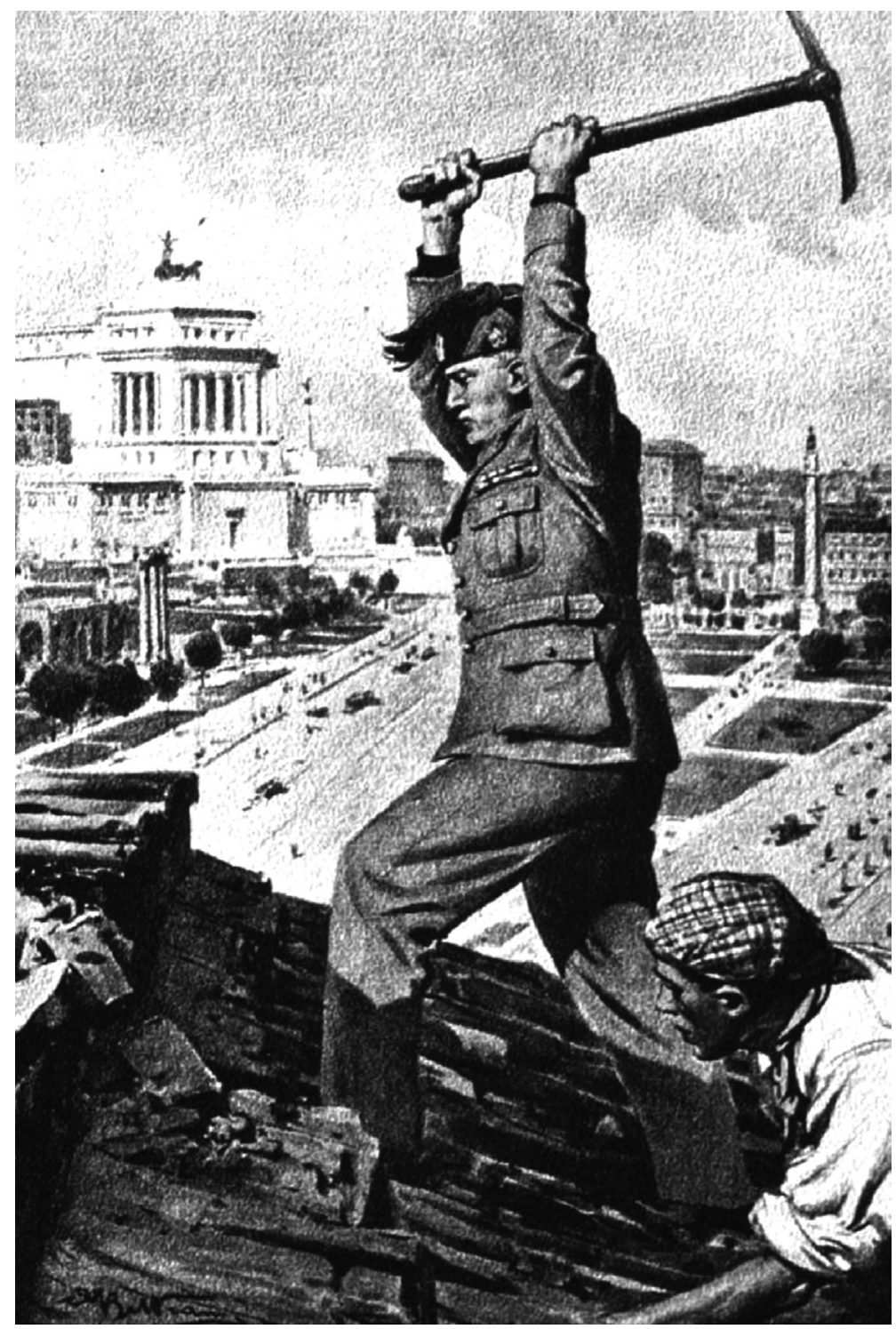

Fig. 9 - Cartaz de propaganda mostrando Mussolini iniciando trabalhos de demolição em Roma. Ao fundo vê-se a nova Via dei Fori Imperiale. (La Domenica del Corriere: 3.3.1935). 


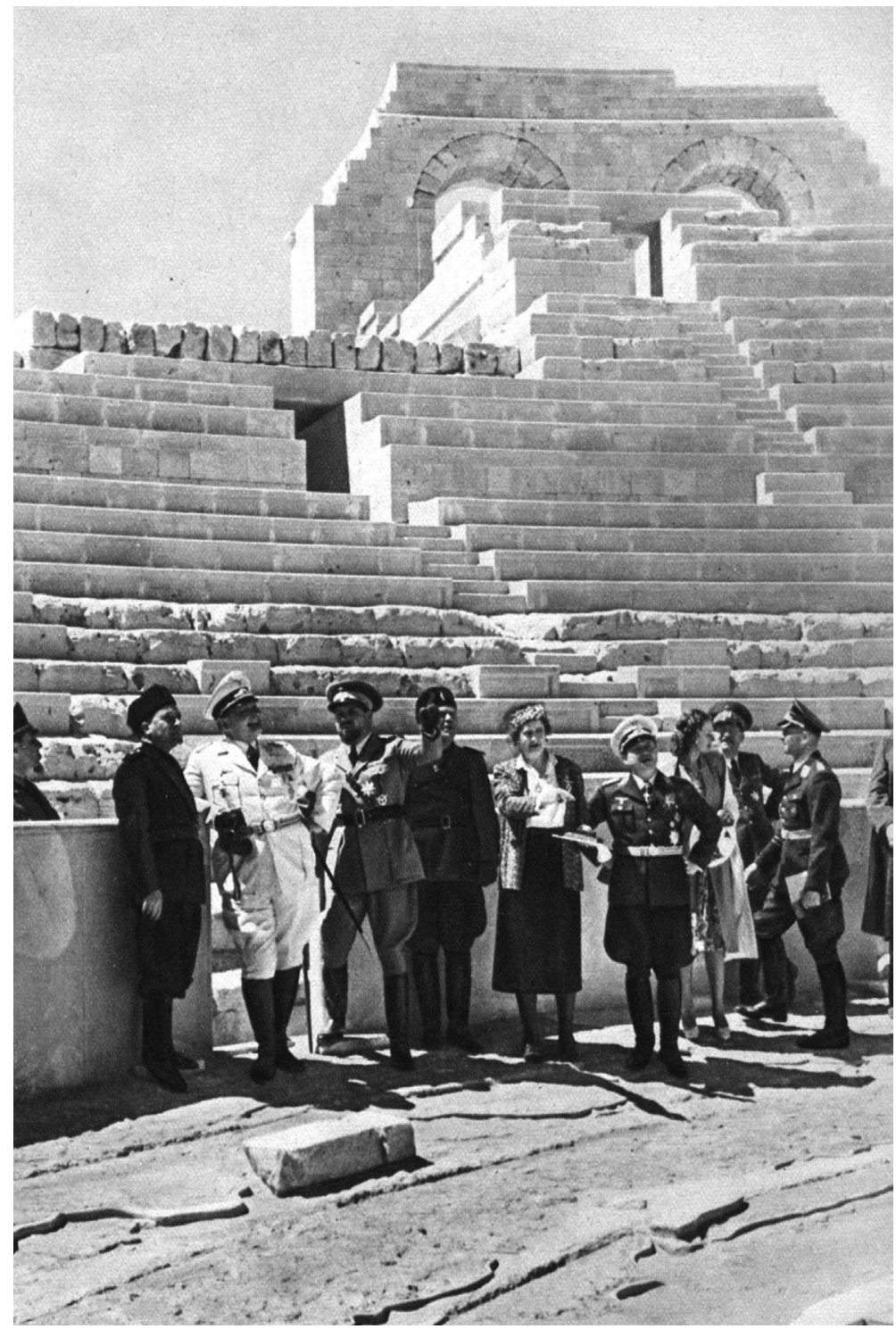

FIG. 10 - Herman Göring e Italo Balbo, governador da Líbia, com outras personalidades em visita ao teatro de Sabratha, restaurado em 1936. (Colecção do autor). 


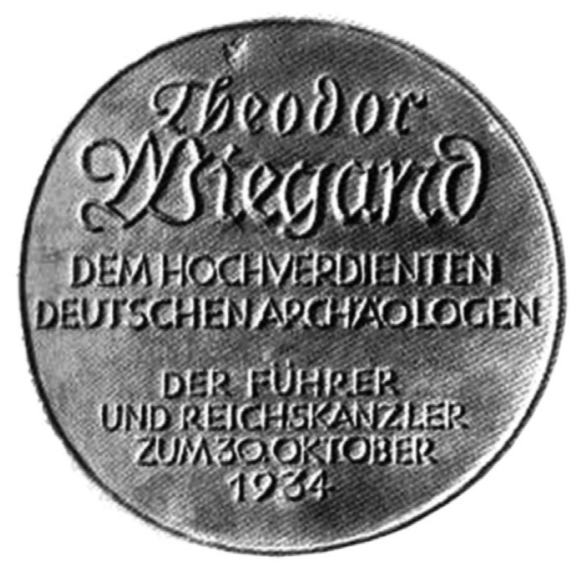

Fig. 11 - Reverso da medalha Adlerschild concedida em 1934 ao arqueólogo Theodor Wiegand. (Apud www.axistory.com)

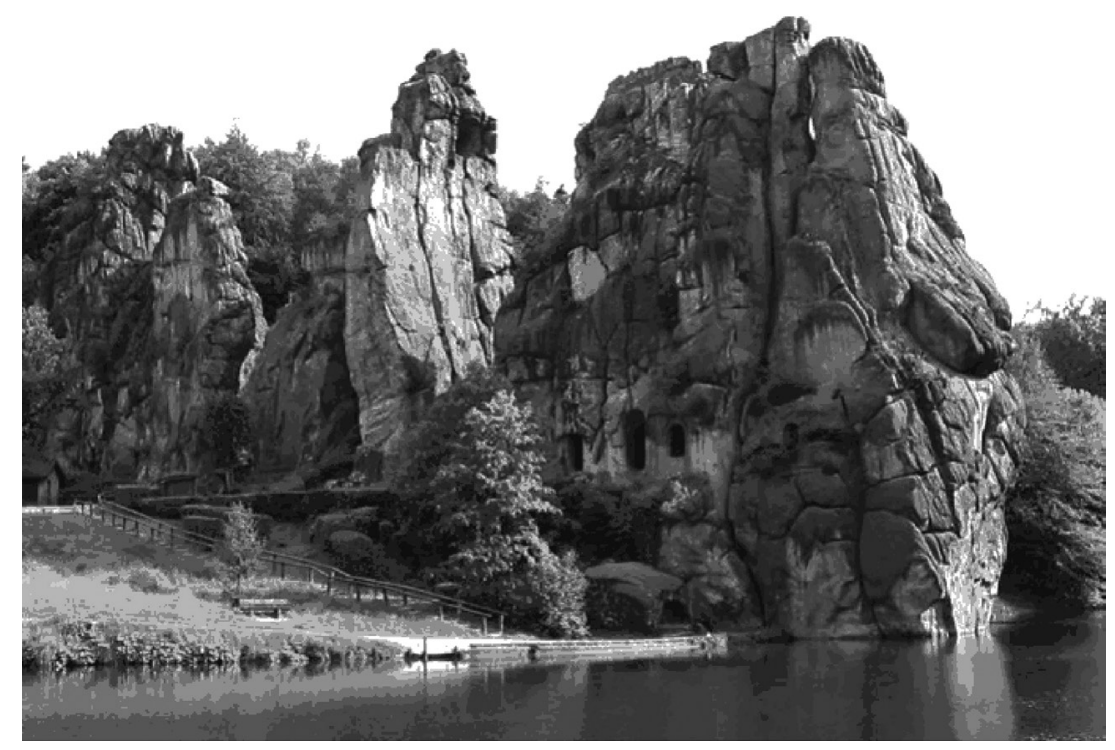

FIG. 12 - O polémico sítio alemão de Externsteine, no distrito de Lippe, possivel local de culto germânico cristianizado. 


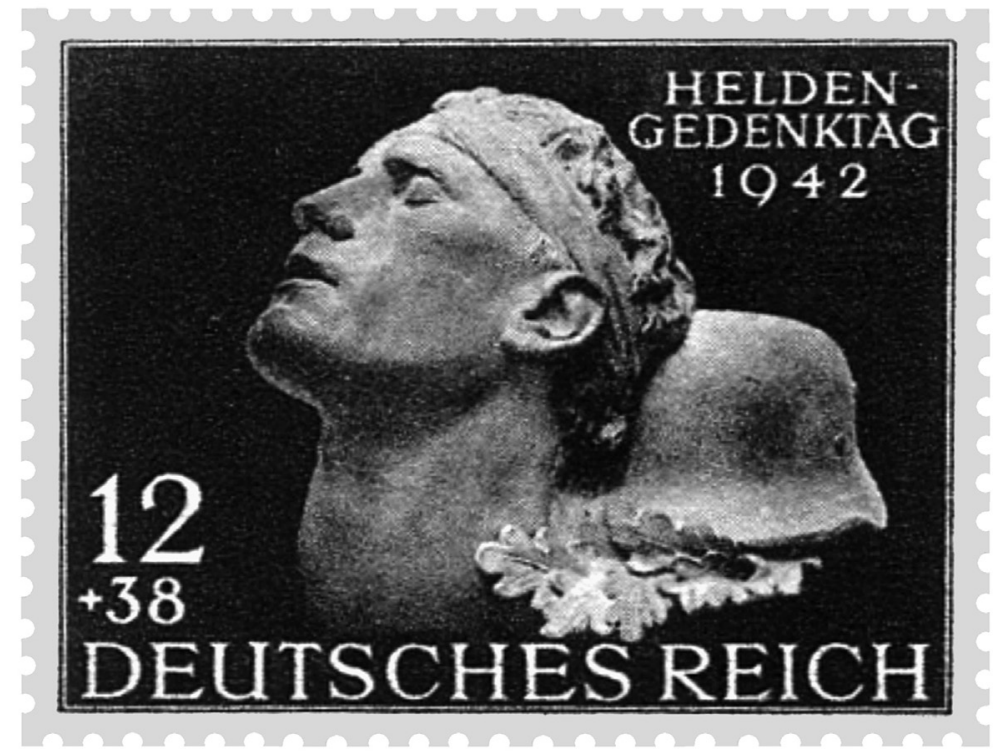

Fig. 13 - Selo alemão comemorativo do Dia dos Heróis de 1942, unindo o Stalhelm a um busto de estética clássica representando o guerreiro morto.

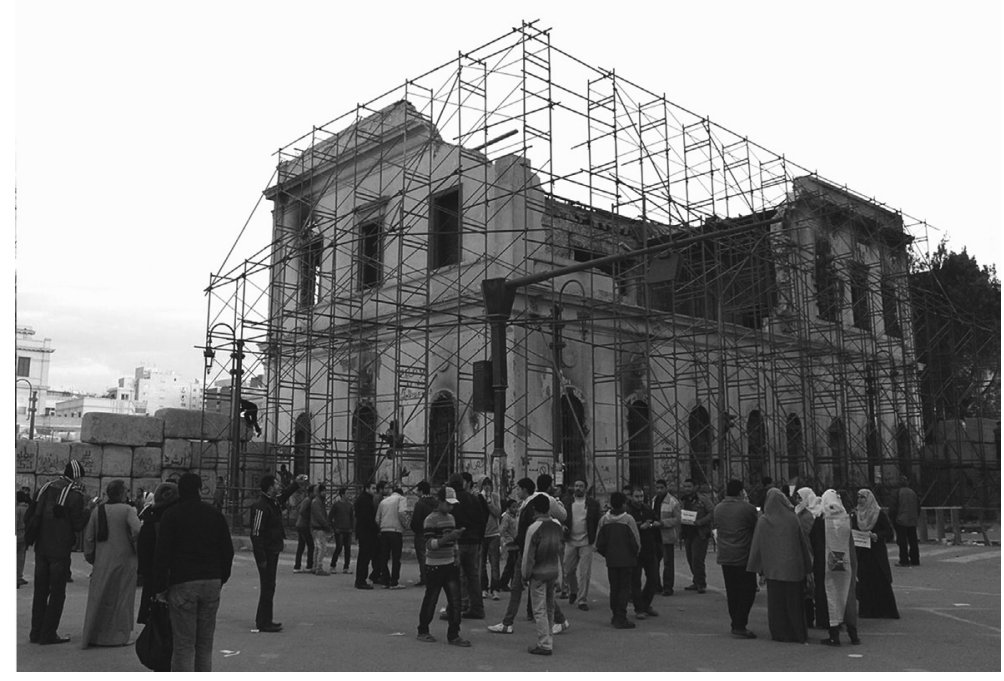

FIG. 14 - O Institut d’Égypte, no Cairo, depois do incêndio que o destruiu em 2012 (Foto: Mohamed Ouda). 

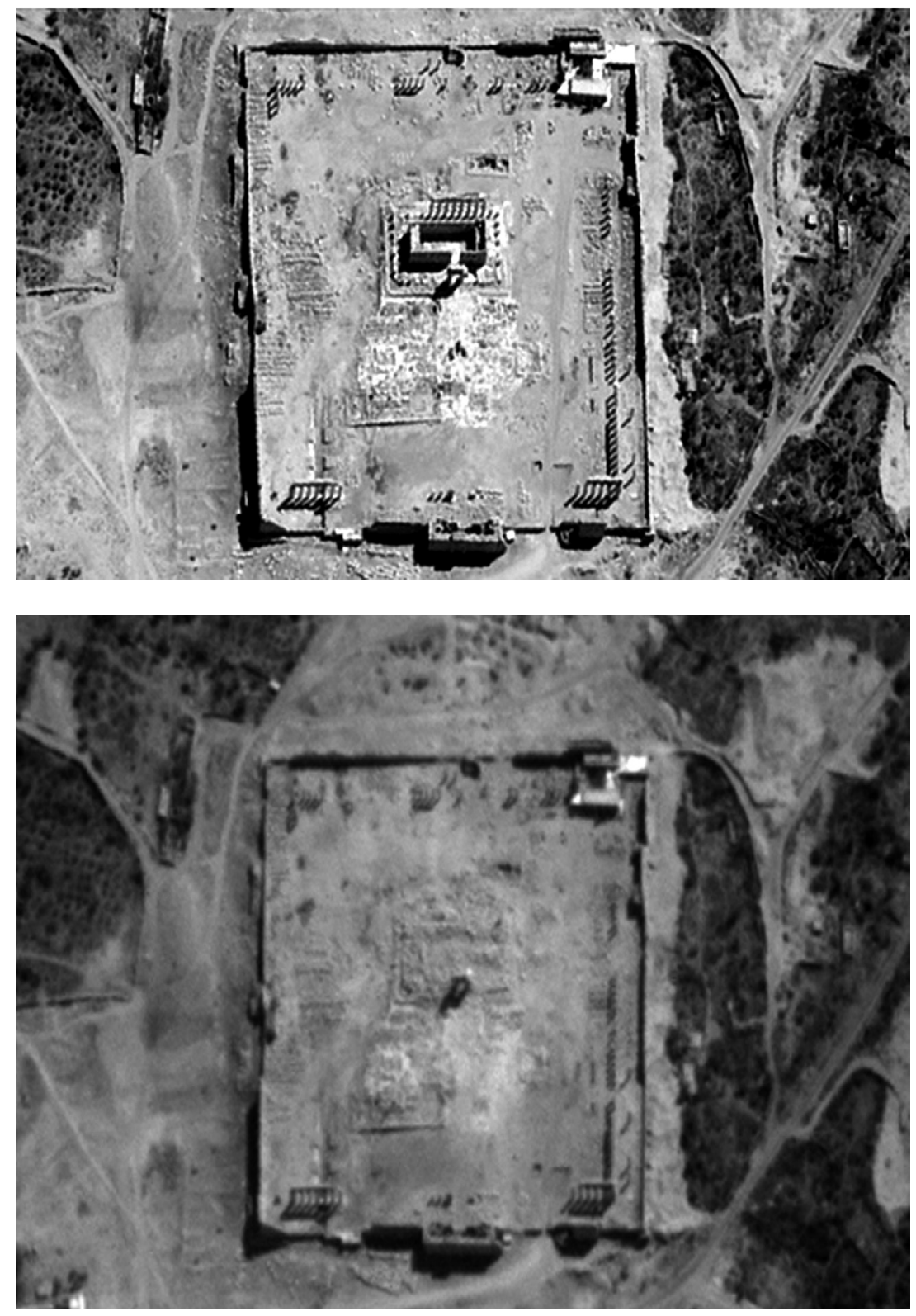

Fig. 15 - Imagens de satélite das ruínas do templo de Bel, em Palmira, antes e depois da destruição em Agosto de 2015. (Imagem UNITAR). 

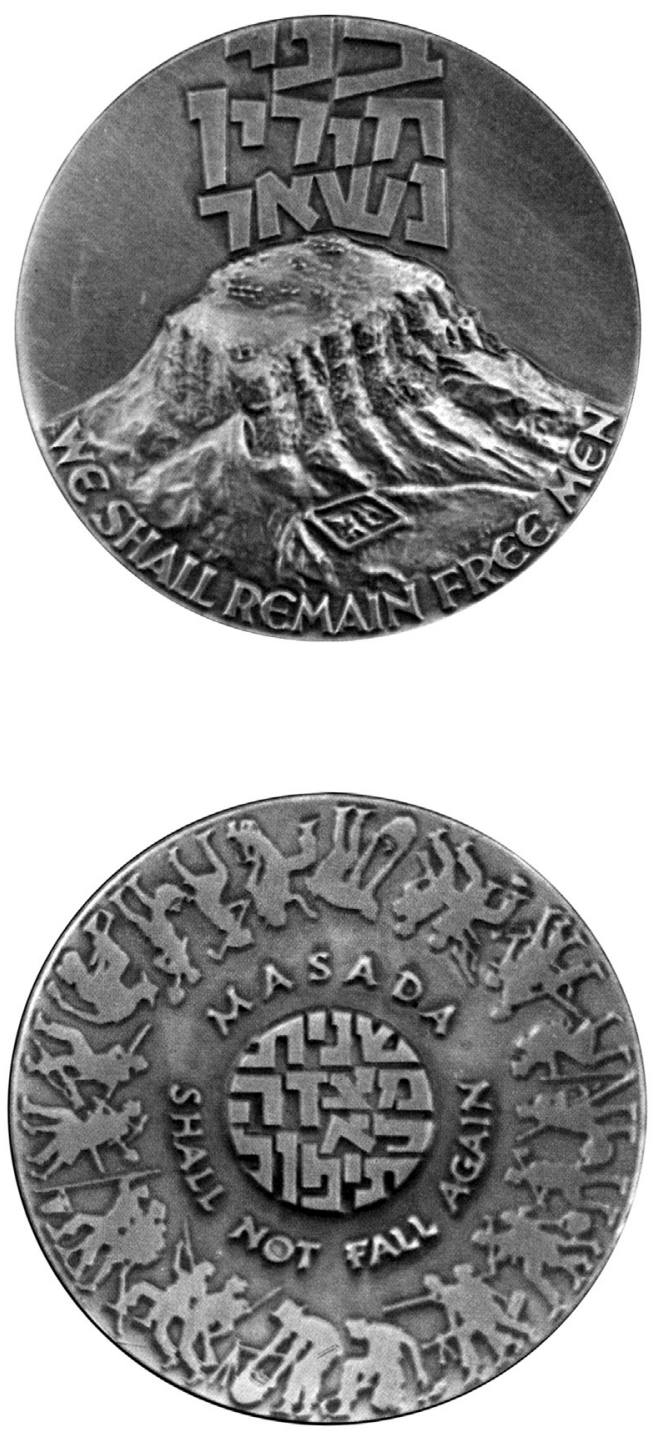

FIG. 16 - Medalha oficial israelita comemorativa das escavações no palácio-fortaleza herodiano de Massada. (Apud Ygael Yadin). 